\title{
REVIEW
}

\section{Life, death, and the pursuit of apoptosis}

\author{
Eileen White \\ Center for Advanced Biotechnology and Medicine and Department of Biological Sciences and the Cancer Institute of New \\ Jersey, Rutgers University, Piscataway, New Jersey 08854 USA
}

Apoptosis or programmed cell death is a genetically controlled response for cells to commit suicide. The symptoms of apoptosis are viability loss accompanied by cytoplasmic boiling, chromatin condensation, and DNA fragmentation (Wyllie 1980). Pathologists and developmental biologists have cataloged the occurrences of apoptosis for many years based on these defined morphological features, but what has propelled apoptosis into the forefront of basic research has been the identification of genes that control cell death and the appreciation of the role of apoptosis in development and disease. Regulation of cell death is essential for normal development and is an important defense against viral infection and the emergence of cancer. Too much cell death can lead to impaired development and degenerative diseases, whereas too little cell death can lead to cancer and persistent and sustained viral infection. The process of apoptosis is controlled through the expression of an increasing number of genes conserved in nematodes through mammals and viruses. Some gene products are activators of apoptosis, whereas others are inhibitors and the characterization of the function of these gene products will help to define the process of cell death at the biochemical level.

\section{The ever-expanding Bcl-2 family of apoptosis regulators}

The $b c l-2$ gene was first identified as part of the most common translocation in human B cell follicular lymphoma (Bakhshi et al. 1985; Tsujimoto et al. 1985; Cleary et al. 1986) and overexpression of Bcl-2 in transgenic animal models mimicked human disease (McDonnell et al. 1989; McDonnell and Korsmeyer 1991). Unlike other oncogenes characterized at that time, Bcl-2 had the unusual property of extending cell survival rather than stimulating cell proliferation /Vaux et al. 1988; Hockenbery et al. 1990). Bcl-2 has since been shown to enhance cell survival by inhibiting apoptosis induced under a wide variety of circumstances, suggesting that it is a ubiquitous inhibitor of cell death triggered by multiple routes.

$\mathrm{Bcl}-2$ possesses a putative transmembrane domain at its carboxyl terminus and is found associated with mitochondrial, endoplasmic reticulum, and nuclear membranes. Removal of the transmembrane region of $\mathrm{Bcl}-2$ prevents membrane targeting, whereas the mutant protein retains partial activity, suggesting that membrane targeting of Bcl-2 is not absolutely critical for function
|Oltvai et al. 1993|. Bcl-2 is expressed widely during embryogenesis (LeBrun et al. 1993; Novack and Korsmeyer 1994|, and its expression becomes more restricted in adult tissues to those requiring long-term survival (stem cells, postmitotic neurons, and proliferating zones; Hockenbery et al. 1991).

Apoptosis plays a major role in normal development, and it was expected that gain- or loss-of-function of a death inhibitor such as Bcl-2 would have a phenotype in transgenic mice. Bcl-2 was expected to regulate apoptosis in lymphoid cells because of the role of Bcl-2 in human B cell lymphoma. Targeted Bcl-2 overexpression to the lymphoid system extends normal B cell survival with the persistence of immunoglobulin secreting and memory cells (Nuñez et al. 1991), partly overcomes the scid block to B cell development (Strasser et al. 1994), and produces B cell lymphoma (McDonnell et al. 1989; McDonnell and Korsmeyer 1991). Progression to highgrade lymphoma is clonal and frequently coincides with a c-myc translocation. In $\mathrm{T}$ cells, ectopic Bcl-2 expression produces increased resistance to apoptosis induced by glucocoticoids, radiation, anti-CD3, PMA, and ionomycin and, to a variable degree, affected negative selection (Sentman et al. 1991; Strasser et al. 1991; Siegel et al. 1992). Bcl-2 also has the capacity to promote neuronal survival (Garcia et al. 1992; Allsopp et al. 1993; Farlie et al. 1995). The ability of Bcl-2 to extend cell survival by preventing cell death in vivo in different cell types and in response to different stimuli suggests that Bcl-2, or Bcl2-like molecules, act at a central, controlling point in the pathway to apoptotic cell death.

Mice with loss-of-function mutations in the $b c l-2$ gene (knockout mice) have been generated by homologous recombination. These mice, which lack Bcl-2 protein, are surprisingly normal at birth, but possess impaired kidney development, and later progress to polycystic kidney disease. The absence of Bcl-2 also produces catastrophic postnatal immune function failure attributable to dramatic loss of mature $B$ and $T$ cells through apoptosis (Nakayama et al. 1993, 1994; Veis et al. 1993; Kamada et al. 1995). Hair hypopigmentation arises at the second hair follicle cycle, apparently because of death of melanocytes (Kamada et al. 1995). Distortion of the small intestines, probably because of impaired survival of the progenitor cells at the base of the crypts, has also been reported (Kamada et al. 1995). The unexpected ability of the $b c l-2$ knockout mice to progress through develop- 
ment without severe difficulty suggests possible functional redundancy or that other Bcl-2 family members may have a more critical role. Thus, inappropriate gain of $\mathrm{Bcl}-2$ function is associated with cancer, whereas loss of Bcl-2 function has dire but restricted consequences to normal development.

There has been much speculation regarding the biochemical mode of action of Bcl-2. Initial suggestions were that Bcl-2 may work through scavenging reactive oxygen radicals to prevent apoptosis (Hockenbery et al. 1993; Kane et al. 1993). This proposal was based largely on the ability of Bcl-2 to mitigate cell death induced by oxidative damage, although it remained possible that the oxidative damage was a downstream consequence of cell death, minimized by Bcl-2 through blockade of the death process. Further evidence suggests that Bcl-2 can inhibit cell death in cells that lack mitochondrial DNA and thereby respiration (Jacobson et al. 1993), and in the presence of nearly anaerobic conditions (Jacobson and Raff 1995; Shimizu et al. 1995). Thus, the mechanism by which Bcl-2 works does not involve direct inhibition of reactive oxygen radical accumulation. Instead, oxidative damage may be a downstream event in the cell death process. Although a means to induce apoptosis through the generation of reactive oxygen species may exist, it may feed into a common pathway to control apoptosis that can be inhibited by Bcl-2.

$b c l-2$ is no longer a single entity but one member of a growing multigene family (Table 1), with multiple representatives in mammals: $b c l-x$ (Boise et al. 1993), $\mathrm{mcl}-1$ (Kozopas et al. 1993), bax (Oltvai et al. 1993), A1 (Lin et al. 1993), bak (Chittenden et al. 1995a; Farrow et al. 1995; Kiefer et al. 1995), bad (E. Yang et al. 1995); bcl-w (S. Cory, pers. comm.), and the nematode Caenorhabditis elegans: ced-9 (Hengartner et al. 1992; Hengartner and Horvitz 1994a). Viral homologs of Bcl-2 have been found in Epstein-Barr virus (EBV) (BHRF1; Cleary et al. 1986), African swine fever virus (AFSV) (LMW5-HL; Neilan et al. 1993), and adenovirus (E1B 19K; Rao et al. 1992;
White et al. 1992; Boyd et al. 1994; Chiou et al. 1994b). Multiple sequence alignment of the Bcl-2 family members and mutagenesis have identified three conserved regions, $\mathrm{Bcl}-2$ homology region 1,2 , and 3 (BH1, $\mathrm{BH} 2$, and $\mathrm{BH} 3$, that are required for regulation of apoptosis and protein-protein interactions (see below).

The $b c l-x$ gene is highly related to $b c l-2$ and also functions to regulate cell death (Boise et al. 1993). bcl-x transcripts are alternatively spliced into long $(\mathrm{L})$ and short $(\mathrm{S})$ forms. The protein product of the long form derived from the $b c l-x_{\mathrm{L}}$ splice variant functionally resembles $b c l-2$ as a potent inhibitor of cell death. The product derived from the alternatively spliced short form, the $b c l-x_{S}$ splice variant, antagonizes cell death inhibition by the $b c l-x_{\mathrm{L}}$ and $b c l-2$ products (Boise et al. 1993). The BHl and BH2 conserved regions in the Bcl-2 family are spliced out of $\mathrm{Bcl}-\mathrm{x}_{\mathrm{S}}$ suggesting that it may act directly or indirectly as a dominant-interfering $\mathrm{Bcl}-2$ or $\mathrm{Bcl}-\mathrm{x}_{\mathrm{L}}$ antagonist. $\mathrm{Bcl}-\mathrm{x}$ is expressed widely in development, particularly in brain and kidney, with the highest levels expressed in the thymus in adult tissue (Boise et al. 1993; Krajewski et al. 1994; Motoyama et al. 1995). In contrast to the bcl-2 knockout mice, the $b c l-x$ knockout mice have an embryonic lethal phenotype around embryonic day 13 (E13) with massive apoptosis in the brain and spinal cord, particularly among differentiating neurons and in the hematopoietic system (Motoyama et al. 1995). Chimeric mice nullizygous for $b c l-x$ in the lymphoid system demonstrated the requirement for $b c l-x$ expression for maintaining the life span of immature but not mature lymphocytes (Motoyama et al. 1995). Thus, $b c l-x$ and $b c l-2$ are complementary in function as apoptosis inhibitors in mouse development.

Mcl-1 was cloned in a screen for genes with increased expression when a human myeloblastic leukemia cell line was induced to differentiate by phorbol ester (Kozopas et al. 1993). Mcl-1 is considerably larger than Bcl-2. The carboxy-terminal half of Mcl-1 displays homology with Bcl-2, whereas the amino-terminal half contains

Table 1. Members of the Bcl-2 family

\begin{tabular}{|c|c|}
\hline Gene product & Function \\
\hline $\mathrm{Bcl}-2$ & inhibitor of apoptosis, binds Bax and Bak (Vaux et al. 1988; Hockenbery et al. 1990) \\
\hline Bcl-x & L form inhibits apoptosis, $\mathrm{S}$ form accelerates apoptosis, binds Bax and Bak (Boise et al. 1993) \\
\hline $\mathrm{Bcl}-\mathrm{w}$ & inhibitor of apoptosis (S. Cory, pers. comm.) \\
\hline Bax & accelerator of apoptosis, binds Bcl-2, Bcl- $x_{L}$, E1B 19K (Oltvai et al. 1993) \\
\hline Bak & $\begin{array}{l}\text { accelerator of apoptosis, can also be inhibitor, binds Bcl-2, Bcl-x, and E1B 19K (Chittenden et al. 1995a; } \\
\text { Farrow et al. 1995; Kiefer et al. 1995) }\end{array}$ \\
\hline Mcl-1 & inhibitor of apoptosis (Kozopas et al. 1993; Reynolds et al. 1994) \\
\hline Al & sequence homology with Bcl-2 (Lin et al. 1993) \\
\hline Bad & accelerator of apoptosis, binds Bcl-2 and Bcl- $x_{\mathrm{L}}$ (E. Yang et al. 1995) \\
\hline Nbk, Bikl & $\begin{array}{l}\text { accelerator of apoptosis, binds Bcl-2, ElB } 19 \mathrm{~K}, \mathrm{Bcl}-\mathrm{x}_{\mathrm{L}} \text { and BHRF1, has only BH3 domain (Boyd et al. } \\
\text { 1995; J. Han and E. White; K. Pun, S. N. Farrow, T. Raven, C. J. Wride, J. H. M. White, and R. Brown; } \\
\text { both in prep.). }\end{array}$ \\
\hline Ced-9 & C. elegans cell death inhibitor, homology to Bcl-2 (Hengartner and Horvitz 1994a) \\
\hline ASFV HMW5-HL & African swine fever virus Bcl-2 homolog (Neilan et al. 1993) \\
\hline EBV BHRF1 & EBV Bcl-2 homolog that inhibits apoptosis (Cleary et al. 1986; Henderson et al. 1993) \\
\hline ElB $19 \mathrm{~K}$ & $\begin{array}{l}\text { adenovirus inhibitor of apoptosis, binds Bax and Bak (White et al. 1992; Farrow et al. 1995; Han et al. } \\
\text { 1995! }\end{array}$ \\
\hline
\end{tabular}


putative PEST sequences suggesting that it may have a short half-life. Mcl-1 appears to localize to membranes similarly to Bcl-2 (T. Yang et al. 1995), and like Bcl-2, Mcl-1 expression delays apoptosis induced by deregulated c-myc (Reynolds et al. 1994). It will be interesting to determine the expression and function of $\mathrm{Mcl}-1$ during development because of the coincidence of $\mathrm{mcl}-1$ mRNA induction in a differentiating cell system and the suggestion that Mcl-1 may have a rapid turnover. Another $b c l-2$ family member, $A 1$, which was isolated from mouse bone marrow induced to proliferate with granulocyte macrphage colony-stimulating factor (GM-CSF), resembles an early response gene and is transcriptionally induced by GM-CSF (Lin et al. 1993). For these reasons Al will also be interesting to examine for its role in development.

Bak was isolated based on its sequence homology to $\mathrm{Bcl}-2$ within the $\mathrm{BH} 1$ and $\mathrm{BH} 2$ regions and its ability to interact with the E1B $19 \mathrm{~K}$ protein /Chittenden et al. 1995a; Farrow et al. 1995; Kiefer et al. 1995). Bak is expressed widely and, in most cases, accelerates cell death, although in an EBV-transformed cell line it seemed to have a protective function. If $\mathrm{Bcl}-2$ family members regulate apoptosis in part by interacting with each other, the context of expression may be a very important determining factor as to whether they act as an antagonist by binding to a death protector or act as a death activator. $\mathrm{BCl}-\mathrm{W}$ was isolated by degenerative PCR based on conserved sequences within $\mathrm{BH} 1$ and $\mathrm{BH} 2$, is highly homologous to Bcl-2 and, like Bcl-2, acts to promote survival (S. Cory, pers. comm.). Bad appears to promote cell death and was isolated based on its ability to interact with $\mathrm{Bcl}-2$ in yeast two-hybrid assays and by expression cloning (E. Yang et al. 1995). Homology between Bcl-2 and $\mathrm{Bad}$ is limited to the $\mathrm{BH} 1$ and $\mathrm{BH} 2$ regions.

Genes that regulate cell death in $C$. elegans development have also been characterized and have been very informative (Hengartner and Horvitz 1994b). The ced-9 gene product is functionally analogous to $b c l-2$ in that it is required to inhibit cell death, which in the worm is induced by the products of the ced-4 and ced-3 genes (Hengartner et al. 1992). The ced-9 gene turned out to be a member of the bcl-2 family and can be functionally substituted for by $b c l-2$ (Vaux et al. 1992; Hengartner and Horvitz 1994a). Thus, there is dramatic functional and structural conservation among the apoptosis regulators.

Of the viral counterparts to Bcl-2, the adenovirus E1B $19 \mathrm{~K}$ protein is the best characterized and is required to block apoptosis during adenovirus infection and transformation (White 1994a, 1995). Failure to suppress apoptosis in productively infected cells compromises virus production because of the premature death of the infected host cell. The E1B $19 \mathrm{~K}$ and Bcl-2 proteins are functionally interchangeable in adenovirus infection and transformation, although the E1B $19 \mathrm{~K}$ protein is more effective at blocking apoptosis induced by tumor necrosis factor $\alpha(T N F \alpha)$ and Fas pathways (White and Cipriani 1990; Gooding et al. 1991; Hashimoto et al. 1991; Rao et al. 1992; White et al. 1992; Debbas and White 1993;
Chiou et al. 1994a,b; Sabbatini et al. 1995a). Amino acid sequence homology is apparent between $19 \mathrm{~K}$ and $\mathrm{Bcl}-2$ family members, and regions of the $19 \mathrm{~K}$ protein known to be important for structure/function are also conserved in the Bcl-2 family (Boyd et al. 1994; Chiou et al. 1994b; White et al. 1992). The Bcl-2 homolog of EBV, the BHRF-1 protein, also functions as an apoptosis inhibitor (Henderson et al. 1993). The role of the ASFV Bcl-2 homolog (LMW5-HL) in the regulation of apoptosis, however, has not yet been established (Neilan et al. 1993).

\section{Bcl-2 family members interact with each other to regulate apoptosis}

How $b c l-2$ family members act to regulate apoptosis is of central importance, and one approach taken by many in the field has been to identify cellular proteins that interact with members of the Bcl-2 family. The first Bcl-2associated protein to be identified was Bax (Oltvai et al. 1993). Bax is homologous to Bcl-2 in sequence and coimmunoprecipitates with Bcl- 2 in cell extracts and in vitro (Oltvai et al. 1993). In functional assays Bax suppresses the ability of Bcl-2 to block apoptosis (Oltvai et al. 1993). Thus, not all bcl-2 family members are inhibitors of apoptosis, but instead some may regulate apoptosis by functional antagonism through the formation of heterodimers. A similar example was found with the $\mathrm{Bcl}-\mathrm{x}$ proteins, where the $b c l-x_{\mathrm{L}}$ splice variant is a potent inhibitor of cell death and the $b c l-x_{S}$ splice variant antagonizes cell death inhibition by the $b c l-x_{L}$ product (Boise et al. 1993). Bcl- $\mathrm{x}_{\mathrm{L}}$ can interact with $\mathrm{Bcl}-\mathrm{x}_{\mathrm{S}}$ in yeast twohybrid assays (Sato et al. 1994), but a direct interaction in mammalian cells has not been established.

Bax knockout mice develop normally but display lymphoid hyperplasia consistent with a role for Bax in the promotion of apoptosis (Knudson et al. 1995). Surprisingly, Bax deficiency also causes male sterility because of the cessation of sperm production (Knudson et al. 1995|. The absence of condensed IN spermatozoa and the presence of apoptotic germ cells suggest that Bax is required to block apoptosis in spermatogenesis. Bax expression is therefore required to either promote or inhibit cell death depending on the cellular context. Alternatively, Bax may be required to eliminate a specific cell type in development that if retained in bax $-/-$ mice would produce inappropriate cell death in spermatogenesis. This model would retain Bax exclusively as a death activator.

The bad gene product, although isolated based on its ability to interact with $\mathrm{Bcl}-2$, interacts more strongly with Bcl- $\mathrm{x}_{\mathrm{L}}$ but does not interact with Bax (E. Yang et al. 1995). Bad can antagonize apoptosis protection by displacing Bax from Bcl- $\mathrm{x}_{\mathrm{L}}$ in vivo. Bak interacts with Bcl$\mathrm{x}_{\mathrm{L}}$, and $\mathrm{E} 1 \mathrm{~B} 19 \mathrm{~K}$ proteins and can inhibit their ability, and also that of Bcl-2, to block apoptosis (Chittenden et al. 1995a; Farrow et al. 1995; Kiefer et al. 1995). The E1B $19 \mathrm{~K}$ protein also interacts with Bax, and Bax can promote apoptosis when overexpressed with respect to the E1B $19 \mathrm{~K}$ protein (Han et al. 1996). Interestingly, a 28-aminoacid region of $\mathrm{Bax}$ encompassing $\mathrm{BH} 3$ is sufficient to interact with the $\mathrm{E} 1 \mathrm{~B} 19 \mathrm{~K}$ and Bcl-2 proteins in yeast 
(Han et al. 1996). Similarly, BH3 of Bak is required for interaction with $\mathrm{Bcl}-\mathrm{x}_{\mathrm{L}}$ in yeast and in vitro /Chittenden et al. 1995b). The interaction of Bax BH3 requires the central conserved region of the E1B $19 \mathrm{~K}$ protein encompassing $\mathrm{BH} 1-\mathrm{BH} 3$, suggesting that all three regions participate in protein-protein interactions in a nonsymmetrical fashion (Han et al. 1996). Most interestingly, a 50amino-acid region of Bak encompassing $\mathrm{BH} 3$, but excluding $\mathrm{BH} 1$ and $\mathrm{BH} 2$, is sufficient to induce apoptosis when expressed in mammalian cells (Chittenden et al. 1995b). Thus, Bak and presumably Bax, may encode a death effector domain in the vicinity of the $\mathrm{BH} 3$ region, or $\mathrm{BH} 3$ may merely serve as the binding site to interact with Bcl-2, E1B 19K, and Bcl- $\mathrm{x}_{\mathrm{L}}$ and neutralize their protective activity. Mutations within $\mathrm{BH} 3$ that do or do not separate binding from cell death will be informative to address this key issue.

The observation that such a small region of $B a x$ is sufficient to confer the ability of Bax to interact with other members of the Bcl-2 family suggested that other proteins not obviously similar to the Bcl-2 could interact with Bcl-2 via this region (Han et al. 1996). Nbk (also known as Bik1) was isolated from a two-hybrid screen using the $\mathrm{E} 1 \mathrm{~B} 19 \mathrm{~K}$ protein as bait, interacts with the $\mathrm{E} 1 \mathrm{~B}$ 19K, Bcl-2, BHRFl, and Bcl- $\mathrm{x}_{\mathrm{L}}$, and contains a BH3 homologous region but not sequences homologous to $\mathrm{BH}$ and BH2 (Boyd et al. 1995; J. Han and E. White; K.-T. Pun, S.N. Farrow, T. Raven, C.J. Wride, J.H.M. White, and R. Brown; both in prep.). Nbk promotes cell death, suggesting that $\mathrm{BH} 3$ may be another indicator of a potential cell death regulator. Again, whether Nbk works through antagonism of Bcl-2-like proteins or acts as a death effect has not yet been established.

The overall theme that emerges is that protectors and promoters of cell death interact with each other and the outcome that prevails depends on the ratio of the death promoter to the death suppressor. A model whereby Bcl-2 family members regulate apoptosis by forming homodimers and heterodimers has been proposed/Oltvai et al. 1993), although it is still not clear which Bcl-2 family member is the antagonist and which is the effector. One hint that Bax may be a death effector that is functionally sequestered by $\mathrm{Bcl}-2$ comes from the observation that BHl mutants of Bcl-2 both fail to associate with Bax and suppress apoptosis but are still capable of forming Bcl-2 homodimers (Yin et al. 1994). The observations that Bax and Bak can act as both inducers and inhibitors of apoptosis suggests that the cellular context of expression may be a determining factor (Kiefer et al. 1995; Knudson et al. 1995). These studies and others, although informative, have not yet established a biochemical function for Bcl-2 or Bax. Further clues may be expected to come from the association of Bcl-2 family members with proteins outside the Bcl-2 family.

\section{Interactions between Bcl-2 and nonfamily members}

One intriguing result was the isolation of R-ras from a yeast two-hybrid screen for Bcl-2-interacting proteins
(Fernandez-Sarabia and Bischoff 1994). R-ras and Bcl-2 also coimmunoprecipitate with each other in extracts from mammalian cells, suggesting that both associate in vivo (Fernandez-Sarabia and Bischoff 1994) and R-ras expression antagonizes the ability of $\mathrm{Bcl}-2$ to block apoptosis (H.-G. Wang et al. 1995). Bcl-2 may regulate R-ras function directly, or vice versa. In contrast to R-ras, expression of a transforming Harvey-ras (H-ras) gene with a mutation that leads to constitutive activation, can protect against apoptosis (Lin et al. 1995). As H-ras regulates several signal transduction pathways, it may provide a link between $\mathrm{Bcl}-2$ and growth factor/cytokine pathways to control apoptosis. There is evidence that $\mathrm{Bcl}-2$ may be regulated by phosphorylation (Haldar et al. 1995), suggesting that growth factors act upstream of Bcl-2 to regulate its function.

Growth factor or cytokine withdrawal from dependent cell lines commonly induces apoptosis in transformed mammalian cell lines. Stimulation of cell growth by c-myc deregulation, for example, necessitates the presence of growth factors such as IGF-I to prevent apoptosis (Harrington et al. 1994). Bcl-2 expression can block apoptosis in cells expressing deregulated c-myc that are factor deprived (Bissonnette et al. 1992; Fanidi et al. 1992), suggesting that growth factors and cytokines can function by providing a constant signal to suppress apoptosis. IGF-II can suppress apoptosis during oncogenesis in vivo, which may represent an efficient means for restricting inappropriate cell growth (Christofori et al. 1994). Presumably, factor withdrawal alters signals transduced to the cell death machinery, perhaps through a Ras pathway, to implement or suppress the death program.

Other proteins that interact with Bcl-2 have been reported such as Bag-1, which was isolated by a $\lambda$ expression cloning strategy and enhances protection from cell death by Bcl-2, although the mechanism has yet to be established (Takayama et al. 1995). Still other Bcl-2 family member interacting proteins have been identified but in vivo association and functional relevance to apoptosis is so far lacking (Boyd et al. 1994). Whereas Bcl-2 appears to interact with numerous proteins, we expect that some will turn out to be physiologically irrelevant and others may be cell type specific.

\section{Other regulators of apoptosis}

Although Bcl-2-related proteins have received most of the attention, other non-Bcl-2-like proteins have been identified as regulators of apoptosis and are likely to be of great importance as well (Table 2). The best examples are the baculovirus $p 35$ and iap genes. p35 and lap independently inhibit apoptosis in baculovirus-infected insect cells and thereby enhance virus production (Clem et al. 1991; Clem and Miller 1993, 1994), much in the same way that E1B $19 \mathrm{~K}$ protein functions during adenovirus infection. p35 may act as a cysteine protease inhibitor to block apoptosis (Bump et al. 1995) and may functionally resemble the cowpox CrmA protein (see below). Re- 
Table 2. Non-Bcl-2-related apoptosis regulators

\begin{tabular}{|c|c|}
\hline Gene product & Function \\
\hline TNF-R1 & $\begin{array}{l}\text { cell-surface receptor that when cross-linked by ligand (TNFo) promote apoptosis in the absence of new } \\
\text { protein synthesis, contains cytoplasmic "death domain," apoptosis is CrmA inhibitable (Smith et al. } \\
\text { 1994; Cleveland and Ihle, 1995) }\end{array}$ \\
\hline Fas/Apol/CD95 & $\begin{array}{l}\text { cell-surface receptor of the TNF receptor family that when cross-linked by Fas ligand or anti-Fas } \\
\text { antibody promotes apoptosis in the absence of new protein synthesis, death induction requires } \\
\text { cytoplasmic death domain, apoptosis is CrmA inhibitable (Nagata and Golstein 1995) }\end{array}$ \\
\hline Death domain proteins & $\begin{array}{l}\text { Other death domain-containing proteins that may mediate transduction of the death signal by TNF-Rl } \\
\text { and Fas (see text) (Cleveland and Ihle 1995) }\end{array}$ \\
\hline Reaper, Hid & $\begin{array}{l}\text { Drosophila death-including gene products that have homology to death domain of Fas/TNF receptors } \\
\text { (White et al. 1994; Golstein et al. 1995; Grether et al. } 1995\end{array}$ \\
\hline p35 & $\begin{array}{l}\text { baculovirus inhibitor of apoptosis, binds to and inhibits ICE family proteases (Clem et al. 1991; Bump et } \\
\text { al. 1995) }\end{array}$ \\
\hline CrmA & $\begin{array}{l}\text { cowpox ICE inhibitor that blocks ICE-dependent apoptosis (Ray et al. 1992; Gagliardini et al. 1994; } \\
\text { Komiyama et al. 1994)) }\end{array}$ \\
\hline ICE family & $\begin{array}{l}\text { family of cysteine proteases that induce apoptosis, includes the C. elegans Ced-3 gene product } \\
\text { (Thornberry et al. 1992; Yuan et al. 1993) }\end{array}$ \\
\hline Dadl & inhibitor of apoptosis (Nakashima et al. 1993) \\
\hline Ced-4 & $\begin{array}{l}\text { C. elegans gene product that induces cell death, inhibitable by Ced-9, no mammalian homolog identified } \\
\text { so far (Ellis and Horvitz 1986) }\end{array}$ \\
\hline Survival factors & $\begin{array}{l}\text { subset of growth factors and cytokines such as IGF-1 and various interleukins that act to promote cell } \\
\text { survival (Raff 1992; Harrington et al. 1994) }\end{array}$ \\
\hline
\end{tabular}

Regulators exclude transcription regulators and kinases.

cently, the candidate gene responsible for the human disease spinal muscular atrophy (SMA), the second most common fatal human autosomal recessive disorder, has been identified, and the predicted protein product shows homology with baculovirus Iap (Lefebvre et al. 1995; Roy et al. 1995). Loss of function of an apoptosis inhibitor such as the SMA gene product is consistent with the excessive and inappropriate apoptosis of motor neurons observed in SMA patients and may contribute to the SMA phenotype. The mechanism of action of iap-related genes, and relationship, if any, to Bcl-2 function, will therefore be of direct relevance to degenerative human diseases.

The function of still other novel apoptosis regulators such as the mammalian dad-1 and the Drosophila melanogaster reaper genes remain to be characterized. Dad-1 acts as an apoptosis inhibitor, but no clue to the mechanism of Dad-1 function can be extrapolated from its sequence (Nakashima et al. 1993). reaper function is required for and sufficient to induce apoptosis in Drosophila development (White et al. 1994). Reaper encodes a polypeptide of only 65 amino acids, but limited sequence homology between Reaper and the "death domain" of mammalian Fas antigen and TNFRl suggests that Reaper may signal death in a similar fashion /Golstein et al. 1995). Recently, the hid gene of Drosophila has been identified as functionally similar to reaper in that it is sufficient for cell death when expressed in cell deathdefective mutants, and a loss of hid function dramatically decreases cell death in embryos (Grether et al. 1995). Obviously, suppressors and modifiers of reaper and hid that can be identified and exploited genetically in Drosophila will be invaluable for elucidating the controlling elements in cell death, many of which would be expected to have mammalian counterparts or homologs. In mammalian cells, Fas antigen (also known as Apo-l or CD95) and TNFR1 induce apoptosis when engaged with ligand (either Fas ligand or $T N F \alpha$, respectively), and the oligomerization of a conserved segment of the cytoplasmic region of these cell-surface receptors designated the death domain is responsible for signaling the apoptotic response (Nagata and Golstein 1995). Fas and TNFR1 death domains associate with the death domains of other cellular proteins such as FADD /Chinnaiyan et al. 1995) or MORT-1 (Boldin et al. 1995), TRADD (Hsu et al. 1995), RIP (Stanger et al. 1995), and FAF-1 (Chu et al. 1996), and stimulate apoptosis (Smith et al. 1994; Cleveland and Ihle 1995). How these death-domain interactions lead to the biochemical events of apoptosis are not yet known, but presumably they activate signal transduction pathways that direct the action of the cell death machinery (see below). A tyrosine phosphatase (FAP-1) has also been identified that associates with the amino terminus of the cytoplasmic domain that is a candidate for negative regulation of the death domain (Sato et al. 1995). In summary, we are at the very beginning in our understanding of apoptosis regulation, but with many of the genes in hand and the direct significance apparent, we can begin to establish the biochemical mechanisms involved.

\section{Tumor suppressor genes $p 53$ and $R b$ regulate apoptosis}

The p53 tumor suppressor gene is the most frequently mutated gene in human tumors/Vogelstein 1990; Hollstein et al. 1991), and reintroduction of p53 into transformed cells can induce either growth arrest (El-Deiry et al. 1993; Harper et al. 1993; Xiong et al. 1993) or apoptosis (Yonish-Rouach et al. 1991). It was attractive to 
think that tumor suppression by p 53 could arise through the activation of cell suicide that is irreversible, rather than through imposition of growth arrest as thought previously, which is inherently reversible. The consensus is that p53 can induce growth arrest or apoptosis depending on the physiological circumstances or cell type, but both activities are potentially involved in tumor suppression.

A role for p53 as an apoptosis regulator in tumor suppression in animal models (Symonds et al. 1994) and in human tumors (Bardeesy et al. 1995) is indicated. p53 accumulates and directs apoptosis in response to DNA damage in skin (Ziegler et al. 1994), thymocytes (Clarke et al. 1993; Lowe et al. 1993b), and intestinal epithelium (Clarke et al. 1994; Merritt et al. 1994). Chemotheraputic agents (Lowe et al. 1993a) and deregulation of normal cell growth control produced by either viral E1A expression during adenovirus infection and transformation (White et al. 1991; Debbas and White 1993; Lowe and Ruley 1993; Chiou et al. 1994b), or constitutive high levels of c-myc expression (Hermeking and Eick 1994; Wagner et al. 1994; Sukamuro et al. 1996), also elicit a similar apoptotic p53-dependent response. p53 is, however, clearly not required for glucocorticoid-mediated apoptosis of thymocytes (Clarke et al. 1993; Lowe et al. $1993 \mathrm{~b}$ ), nor is p53 essential for most but not all aspects of apoptosis in murine development (Donehower et al. 1992; Armstrong et al. 1995). Thus, p53 appears to be a surveillance factor to induce apoptosis under specific circumstances of cellular damage, whereas normal developmental pathways to control apoptosis can operate largely independently of p53.

How p53 directs growth arrest and apoptosis is obviously important and has been the focus of attention of many laboratories. Most evidence suggests that p53 functions as a transcription factor: p53 possesses sequence-specific DNA-binding activity and can activate the transcription of genes that carry a target element within their promoter (El-Deiry et al. 1992). p53 can also repress the transcription of genes that lack a p53-responsive element (Mack et al. 1993), but the biological relevance of this observation is not yet clear. One gene that is activated by $\mathrm{p} 53$ is the $p 21 / W A F-1 /$ cip-1 cell-cycle dependent kinase inhibitor, which is likely responsible, in all or in part, for inhibition of cell cycle progression by p53 (El-Deiry et al. 1993; Harper et al. 1993; Xiong et al. 1993) and not apoptosis (Deng et al. 1995). The role of p53-dependent transcription in apoptosis has been more controversial.

Most evidence suggests that p53 can function as a transcription factor, and this activity is certainly responsible for or contributes to promotion of growth arrest by p53. It is reasonable to suspect that a similar transcription-dependent mechanism might exist for apoptosis. In that case, p53 might activate the transcription of death genes $(b a x)$ or repress the transcription of survival genes (bcl-2). bax expression is depressed, and bcl-2 expression is elevated in tissues from $p 53$ null mice relative to p53expressing wild-type controls (Miyashita et al. 1994). Furthermore, p53 has been reported to stimulate bax expression in promoter-reporter assays in cultured cells
(Miyashita and Reed 1995). The indication from these experiments is that up-regulation of bax transcription is a means by which p53 induces apoptosis. If so, it will be of interest to determine whether p53 is capable of inducing apoptosis in cells rendered null for bax, to establish a direct dependence of p53 on Bax function to induce apoptosis. p53 has also been reported to induce Fas expression, which may represent an alternate, transcriptionally-dependent means for p53 to regulate apoptosis (Owen-Schaub et al. 1995).

In contrast to the suggestion that p53 may activate $b a x$ transcription to induce apoptosis, other evidence suggests that p53 can induce apoptosis in the presence of inhibitors of transcription and protein synthesis, precluding transcriptional activation by $\mathrm{p} 53$ as a sole mechanism of apoptosis induction (Caelles et al. 1994). One is left with the possibility that p53 can induce apoptosis through transcriptional repression or possibly through regulation of DNA repair or replication.

A genetic approach has also been taken to address the requirement of transcriptional activity in p53-dependent apoptosis. p53 contains three functional domains: an amino-terminal transcriptional activation domain; a central sequence-specific DNA-binding domain; and a carboxy-terminal oligimerization domain (Prives 1994). Nearly all of the p53 mutations sequenced from human tumors map within the sequence-specific DNA-binding domain and impair the ability of p53 to bind DNA. Therefore, sequence-specific DNA-binding, and any functional consequence thereof, is essential for tumor suppression. Specific residues within the activation domain that are required for trans-activation of transcription by $\mathrm{p} 53$ have been identified by mutagenesis (Lin et al. 1994). Mutation of residues 22 and 23 within the p53 activation domain dramatically impairs the activity of p53 as a transcription factor, although sequence-specific DNA binding is unaffected (Lin et al. 1994). The 22,23 transcriptionally defective mutant p53 is severely impaired in its ability to induce apoptosis in comparison to p53 possessing a functional activation domain in BRK cells provided with a death stimulus by E1A (Sabbatini et al. 1995b). Thus, in this setting the activity of p53 as a transcription factor is required for apoptosis. A similar inability of p53 to induce apoptosis with a mutationally impaired activation domain has been reported in transient expression assays (Yonish-Rouach et al. 1996). However, p53 can both activate and repress transcription, and the 22,23 mutant can do neither. The 22,23 p53 mutation also abrogates interaction with MDM2 (Lin et al. 1994), but whether this contributes to the failure of the mutant to induce apoptosis has not been determined. We can conclude, however, that the potential exists for p53 to either activate the transcription of death genes or repress the transcription of survival genes, or both.

If the model that the ratio of Bax to Bcl-2 controls cell survival is correct, then either up-regulation of Bax or down-regulation of $\mathrm{Bcl}-2$ would be sufficient to induce apoptosis. Bax expression is up-regulated by wild-type p53 expression but not by expression of the transcriptionally defective p53 mutant, which is in agreement 
with the bax transcriptional activation model for p53dependent apoptosis (Han et al. 1996). Furthermore, ectopic bax expression induces apoptosis where p53 is constitutively in the mutant conformation, suggesting that Bax alone is sufficient to induce apoptosis and acts downstream of p53 (Han et al. 1996). The most plausible explanation is that p53 activates the transcription of genes involved in the induction of both growth arrest and apoptosis through transcriptional activation of $p 21 /$ WAF-1/cip-1 and bax, respectively, and perhaps other genes as well. In situations of simultaneous induction of both growth arrest and apoptosis pathways, apoptosis would prevail over growth arrest as a dominant phenotype. Bcl-2 and E1B 19K proteins both bind to and neutralize Bax function and can thereby block p53-induced, Bax-dependent apoptosis (Oltvai et al. 1993; Chiou et al. 1994a; Han et al. 1996). In that way the apoptotic pathway is blocked, but $p 21 / W A F-1 /$ cip-1 transcriptional activation by $\mathrm{p} 53$ would produce cell cycle arrest, which is exactly the phenotype of cells rescued from p53-dependent apoptosis by Bcl-2 and E1B 19K expression (Chiou et al. 1994a; Lin et al. 1995; Sabbatini et al. 1995a). One function of Bcl-2-like proteins is therefore to control the physiological outcome of p53 function. It is probable, however, that the growth arrest activity of $\mathrm{p} 53$ is only apparent in the E1B $19 \mathrm{~K}$ and Bcl-2 expressing cell lines because of the high levels of expression of p53. E1A expression can overcome cell cycle arrest by p53 in this setting (Lin et al. 1995), and this is problably why ElA and either E1B 19K or Bcl-2 transform cells with no apparent indication of growth arrest (Rao et al. 1992; White et al. 1992).

p53-mediated bax induction may not be the only pathway by which p53 can induce cell death. The same transcriptionally defective 22,23 p53 mutant that is severely compromised in the ability to induce apoptosis in BRK cells (Sabbatini et al. 1995b) is capable of inducing apoptosis as efficiently as wild-type p53 in HeLa cells in transient expression assays (Haupt et al. 1995b). This would be inconsistent with a bax-activation model for apoptosis. Furthermore, bax activation by p53 does not always occur during apoptosis (Canman et al. 1995). The most likely explanation is that p53 can induce apoptosis by both transcriptionally dependent and independent mechanisms, depending on the cell type. In BRK cells, Bax levels are low and induction of apoptosis may require up-regulation of bax expression by p53. Bax levels in HeLa cells are constitutively high, which may obviate the need for Bax induction to induce cell death, and in that setting an alternate, transcription activation-independent pathway for p53-dependent apoptosis may be unmasked. There are now clear examples for the existence of both transcription-dependent (blocked by protein synthesis and transcription inhibitors) and -independent lactivated in the presence of protein synthesis and transcription inhibitors) apoptotic pathways, and p53 apparently has two mechanisms for promoting apoptotic cell death. Whereas bax transcriptional activation is indicated for the p53 transcription-dependent pathway, the nature of the transcription activation-independent path- way has not been established. The carboxyl terminus of p53 has the capacity to recognize damaged DNA and may influence DNA repair mechanisms through an interaction with RPA and TFIIH (Jayaraman and Prives 1995; Lee et al. 1995). Aberrant regulation of DNA repair may, in turn, promote apoptosis. An alternative, but not necessarily mutually exclusive, possibility is that p53 promotes apoptosis through transcriptional repression of survival factors. In some situations, inhibition of transcription or protein synthesis alone is sufficient to induce cell death, suggesting that continual expression of a labile survival factor may be required. p53 can repress transcription of genes that lack p53 response elements and has been reported to repress bcl-2 expression (Miyashita et al. 1994). In support of the repression scenario, E1B 19K and Bcl-2 proteins, which inhibit apoptosis, also block repression by p53 (Shen and Shenk 1994; Sabbatini et al. 1995a). Thus, transcriptional repression by p53 could cause apoptosis, which is prevented by members of the $\mathrm{Bcl}-2$ family. However, it is also possible that repression of transcription is not the cause but rather a symptom of cell death.

The connection between the retinoblastoma tumor suppressor protein $(\mathrm{Rb})$ and apoptosis came from several directions. Apoptosis is one cellular response to E1A expression (White and Stillman 1987; White et al. 1991) and ElA is known to bind to and inhibit Rb (Whyte et al. 1988). Induction of apoptosis by E1A was genetically inseparable from the ability of E1A to stimulate DNA synthesis and bind $\mathrm{p} 300$ and $\mathrm{Rb}$, suggesting that some aspect of deregulation of cell growth control by E1A is responsible for apoptosis (White and Stillman 1987; White et al. 1991). Rb - / - mice die at E12-E13 with the occurrence of profound cell death in the nervous system (Clarke et al. 1992; Jacks et al. 1992; Lee et al. 1992). A loss of Rb function during development apparently produces inappropriate DNA synthesis and apoptosis, suggesting that $\mathrm{Rb}$ function is required in development to inhibit cell cycle progression, thereby avoiding the apoptotic response (Morgenbesser et al. 1994; Pan and Griep 1994). Furthermore, restoring $\mathrm{Rb}$ function by ectopic $\mathrm{Rb}$ expression also inhibits apoptosis (Haas-Kogan et al. 1995; Haupt et al. 1995a). Finally, E2F overexpression produces apoptosis. $\mathrm{Rb}$ normally complexes with and inhibits members of the E2F family of transcription factors, only to release E2F to activate the transcription of genes required for $\mathrm{S}$ phase at the appropriate time in the cell cycle (Nevins 1992; Johnson et al. 1993). Overriding Rb by enforced E2F expression induces both DNA synthesis and apoptosis (Qin et al. 1994; Shan and Lee 1994; Wu and Levine 1994; Kowalik et al. 1995). Moreover, apoptosis occurring through $\mathrm{Rb}$ loss, either by E1A or E2F expression, or in $\mathrm{Rb}-/$ - mice, is substantially p53 dependent (Howes et al. 1994; Morgenbesser et al. 1994; Pan and Griep 1994, 1995). p53 may therefore exist as a failsafe response to inappropriate cell cycle progression that occurs when $\mathrm{Rb}$ function is compromised (White 1994b). This may explain why $R b$ and $p 53$ are frequently both lost in human tumors and why DNA viruses target both $\mathrm{Rb}$ and $\mathrm{p} 53$ for inactivation. 


\section{Role of ICE-related cysteine proteases in apoptosis}

Two genes that are required for induction of programed cell death in C. elegans development, ced-3 and ced-4 (Ellis and Horvitz 1986), are normally kept in check by the bcl-2-like gene, ced-9 (Hengartner et al. 1992; Hengartner and Horvitz 1994a,cl. The ced-3 gene product is highly homologous to human interleukin-1 $\beta$-converting enzyme or ICE (Yuan et al. 1993), a cysteine protease that processes IL-1 $\beta$ to the mature form as part of the inflammatory response (Thornberry et al. 1992). Residues essential for substrate recognition and catalysis are conserved between Ced- 3 and ICE, suggesting that they may have a similar structure and/or substrate specificity (Walker et al. 1994; Wilson et al. 1994). Overexpression of Ced-3 or ICE in mammalian cells induces apoptosis that is inhibitable by Bcl-2 (Miura et al. 1993). More importantly, however, the cowpox $\operatorname{crm} A$ gene product, which binds to and inhibits ICE (Ray et al. 1992; Komiyama et al. 1994), inhibits apoptosis induced not only by ICE (Miura et al. 1993) but by NGF deprivation of neuronal cells (Gagliardini et al. 1994), and by TNF $\alpha$ and Fas antigen (Enarl et al. 1995; Los et al. 1995; Tewari and Dixit 1995). This provides strong evidence that CrmAinhibitable cysteine proteases play an important role in multiple pathways for induction of apoptosis. Other ICErelated genes nedd-2/ich-1 (Kumar et al. 1994; Wang et al. 1994), TX/Ich-2/1CE rel $^{\text {II }}$ (Faucheu et al. 1995; Ka-

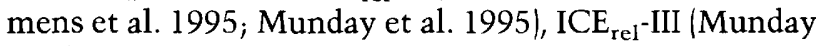
et al. 1995; Nicholson et al. 1995), Mch-2 (FernandesAlnemri et al. 1995), and CPP32 (Alnemri et al. 1995; Fernandes-Alnemri et al. 1994; Tewari et al. 1995|, have been identified whose products similarly induce apoptosis, indicating the existence of a multigene family encoding proteases that potentially regulate apoptosis.

Further support for the role of the ICE family in the regulation of apoptosis has come from experiments with the baculovirus p35 protein. p35 interacts with and inhibits multiple members of the ICE family, including Ced-3 (Bump et al. 1995; Xue and Horvitz 1995), and inhibits developmentally programmed cell death in $C$. elegans (Sugimoto et al. 1994) and Drosophila (Hay et al. 1994; Grether et al. 1995). Inhibition of apoptosis by p35 in mammalian cells has also been reported (Rabizadeh et al. 1993|, but it is too early to tell how ubiquitous this finding will be. Pathways to induce apoptosis in mammalian cells may be more complex or redundant than in lower organisms.

In vitro assays for complex biological processes have been an invaluable tool for defining the biochemical mechanisms involved, of which transcription and DNA replication are just two examples, and systems that mimic many aspects of apoptosis in vitro have been developed (Lazebnik et al. 1993, 1994; Newmeyer et al. 1994). In these assays, nuclei added to primed cytoplasmic extracts, derived from either chicken cells or Xenopus egg extracts, undergo chromatin condensation and DNA fragmentation characteristic of apoptosis. Addition of membrane fractions enriched in Bcl-2 inhibits this process, validating that it is apoptosis (Newmeyer et al. 1994). The ICE family member CPP32 (also known as apopain) has been identified as the enzyme responsible for apoptosis in chicken and mammalian cell extracts. CPP32 activity is present in in vitro extracts, and more importantly, a specific peptide aldehyde inhibitor of CPP32 blocks apoptosis in vitro (Nicholson et al. 1995). Of the ICE members identified to date, CPP32 is the most closely homologous to Ced-3.

ICE - / - mice develop normally but may have a minor defect with respect to Fas-mediated cell death. These results argue against a central role for ICE in the regulation of mammalian cell death (Kuida et al. 1995; Li et al. 1995). The presence of multiple ICE family members might create redundancy in the death pathway such that the loss of any one member may not impact significantly on apoptosis in development. Alternatively, CPP32, or another yet-to-be-characterized ICE family member, may turn out to be essential for apoptosis in development.

Identification of relevant substrates for ICE family members will be important for establishing how cysteine proteases are involved in apoptosis. The best-characterized substrate that has been reported besides IL-1 $\beta$ is poly(ADP) ribose polymerase (PARP) (Lazebnik et al. 1994; Oberhammer et al. 1994). CPP32 has high specificity for PARP and does not cleave IL-1 $\beta$, whereas the converse is true for ICE (Nicholson et al. 1995; Tewari et al. 1995). Unfortunately, neither substrate is likely to control apoptosis directly because IL-1 $\beta$ and poly(ADP)ribosylation-deficient mice develop normally but have restricted, specific defects associated with either inflammation in the case of IL-1 $\beta$ loss (Zheng et al. 1995) or epidermal hyperplasia in the case of ribosylation loss (Z.Q. Wang et al. 1995). However, the epidermal hyperplasia suggests a possible role for PARP specifically in regulating apoptosis in skin in response to environmental stress (Z.-Q. Wang et al. 1995). ICE and CPP32 are, however, likely to have multiple substrates, not all of which may be essential for implementing apoptosis. There is evidence for both nuclear and cytoplasmic events in apoptosis, and substrates for ICE-like activity may reside throughout the cell. Bcl-2 can inhibit apoptosis in cytoplasts that lack a nucleus, suggesting that nuclear events are not required for manifestation of the morphological features of apoptosis in the cytoplasm, and may be independent (Jacobson et al. 1994; Schulze-Ostoff et al. 1994).

Other substrates of ICE-like proteases with a potential role in apoptosis are the nuclear lamins. Lamins are intermediate filament proteins residing at the nuclear envelope that serve to organize chromatin within the nucleus in interphase and are required for reassembly of the nucleus following mitosis (McKeon 1991). Lamin cleavage is an early event in apoptosis (Neamati et al. 1994; Oberhammer et al. 1994), and there is evidence to suggest that an ICE-like protease is responsible (Lazebnik et al. 1995). Inhibition of the lamin protease in vitro blocked some but not all of the nuclear events of apoptotic cell death, suggesting that multiple parallel events are required for completion of the apoptotic program $/ \mathrm{La}$ zebnik et al. 1995). Ultimately, distinct cytoplasmic and 
nuclear proteolytic events in combination may be required for manifestation of apoptosis.

\section{Pathways to control apoptosis}

With many of the regulators of apoptosis identified, it is now possible to begin to define the functional relationships between them. It is likely that apoptosis will be controlled in a cell type-specific fashion, but the basic elements of the death machinery may be universal. In normal settings developmental cues may directly or indirectly control the function of Bcl-2 family members to affect the desired outcome on cell viability (Fig. 1). These cues could come from cell-surface events, modulation of early response regulators, and developmentally programmed changes in gene expression. Coordination between cell cycle and cell death control in development is likely to be important because inappropriate stimulation of DNA synthesis is associated with cell death \{see above).

Pathways to control cell death in development are almost exclusively p53-independent with few exceptions
(Donehower et al. 1992; Armstrong et al. 1995). In damaged cells, however, p53 transcriptional activity may prevail to implement growth arrest or death. DNA damage and inappropriate deregulation of cell growth control provoked by $\mathrm{Rb}$ loss or deregulated $\mathrm{c}-\mathrm{myc}$ can produce p53 accumulation (Lowe and Ruley 1993; Chiou et al. 1994a; Hermeking and Eick 1994) and induction of transciptional activation (and possibly repression) (Prives 1994). Induction of $\mathrm{p} 21 /$ WAF-1/Cip-1 and GADD45 expression inhibits cell cycle progression and facilitates implementation of grow th arrest (Fig. 1). Similarly, stimulation of excess bax expression by p53 (Miyashita et al. 1994; Han et al. 1995; Miyashita and Reed 1995) may disturb the normal ratio of $\mathrm{Bax}$ to $\mathrm{Bcl}-2$ and promote apoptosis (Oltvai et al. 1993). Bcl-2 and E1B 19K overexpression can block p53-dependent apoptosis (Chiou et al. 1994a; Sabbatini et al. 1995al, so apparently Bax induction can be compensated for by the direct interaction of Bax with Bcl-2 or E1B 19K /Oltvai et al. 1993; Han et al. 1996). Simultaneous induction of apoptosis and growth arrest pathways by p53 will create a situation where cell death will be the outcome if Bcl-2-like activity is low,

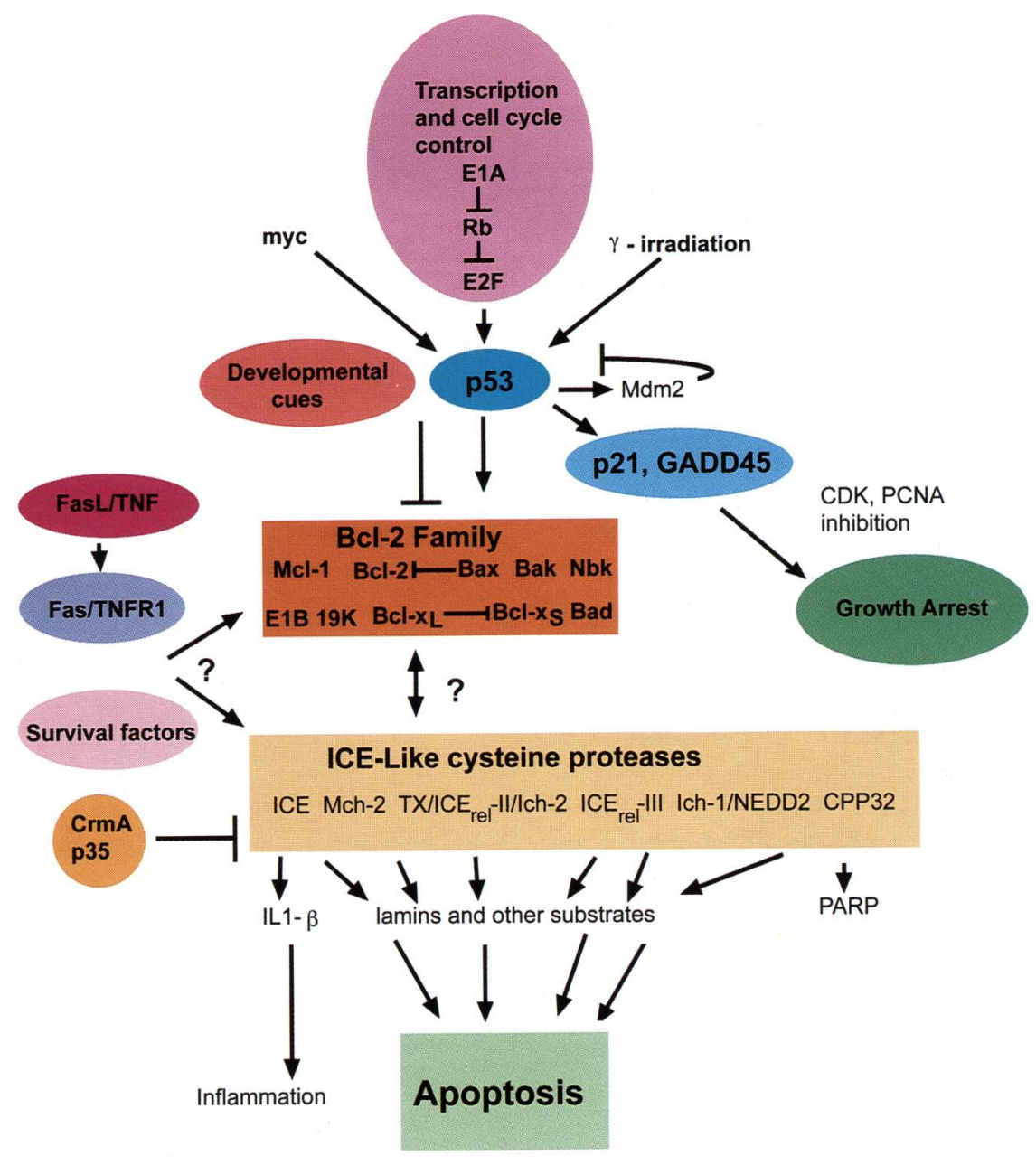

Figure 1. Regulation of apoptosis (see text for explanation). 
whereas growth arrest will occur where a Bcl-2-like activity is at sufficient levels to neutralize Bax (Chiou et al. 1994a; Lin et al. 1995; Sabbatini et al. 1995a). p53 also induces the transcription of its own negative regulator MDM2, which then serves as a negative feedback loop to turn off the activity of p53 (Momand et al. 1992; Oliner et al. 1993). p53 may also induce apoptosis through a transcription-independent mechanism that has not yet been specifically identified (Caelles et al. 1994; Haupt et al. 1995 b).

The biochemical events leading from Bcl-2 and Bax interaction to cell death have not been well established, but the family of ICE-like cysteine proteases are likely to be involved (Fig. 1). There are now numerous members of the ICE family whose expression in cells causes cell death by apoptosis that can be prevented by Bcl-2 (see above). Induction of cell death by over expression of a protease may not be terribly relevant to normal in vivo processes (Williams and Henkart 1994), but inhibition of cell death by expression of ICE family inhibitors such as CrmA or p35 is strong evidence to link cysteine proteases to the apoptotic process. Fas and TNFRl may activate a latent ICE-like activity or modulate the function of the Bcl-2 family to promote cell death. Survival factors could similarly act at either or to modulate members of either the ICE or Bcl-2 family (Fig. 1). Expression of the E1B $19 \mathrm{~K}$ protein efficiently blocks apoptosis induced by both TNF and Fas pathways (results with Bcl-2 are more variable) (White et al. 1992), indicating a fuctional interface between Fas/TNF signaling, the Bcl-2 family, and ICE activity. Whereas CrmA potently inhibits ICE (Komiyama et al. 1994; Ray et al. 1992), it has a variable ability to inhibit other ICE family members (Nicholson et al. 1995). p35 also inhibits multiple ICE family members (Bump et al. 1995). Thus, it is difficult to establish which protease activity is involved in situations of apoptotic cell death. There is likely to be cell type specificity and perhaps functional redundancy among the regulators of apoptosis. Nonetheless, CrmA is an effective inhibitor of Fas- and TNF-mediated apoptosis suggesting that ICE-like protease activity is required for cell death in those pathways (Enarl et al. 1995; Los et al. 1995; Tewari and Dixit 1995). Similarly p35 inhibits apoptosis in worms and flies, and possibly mammalian cells as well, providing further indication for the widespread participation of the ICE family in apoptosis (Rabizadeh et al. 1993; Clem and Miller 1994; Hay et al. 1994; Sugimoto et al. 1994; Grether et al. 1995). Major remaining issues are the functional interactions between the Bcl-2 and ICE families, and the identification of the substrates for the ICE family that presumably, upon cleavage, lead to the next step in the death process. As Bcl-2 will block apoptosis induced by the ICE family, it will be of great interest to determine whether the Bcl-2 family regulates the ICE family at the level of activation, activity, or substrate accessibility and whether the regulation is direct of indirect. Mapping these events, and perhaps those in between or upstream, will ultimately lead to definition of the process of cell death and how it may be controlled in the case of disease.

\section{Acknowledgments}

I thank Terri Grodzicker, Peter Sabbatini, Lakshmi Rao, ShiunKwei Chiou, Denise Perez, Jeonghoon Han, and Gary Kasof for helpful comments and discussions, and I thank numerous investigators for sharing unpublished data. This work was supported by grants from the National Institutes of Health (CA53370, CA60088, and CA64807) and the New Jersey Commission on Science and Technology (to E.W.).

\section{References}

Allsopp, T.E., S. Wyatt, H.F. Paterson, and A.M. Davies. 1993. The proto-oncogene $b c l-2$ can selectively rescue neurotrophic factor-dependent neurons from apoptosis. Cell 73: 295-307.

Alnemri, E.S., T. Fernandes-Alnemri, and G. Litwack. 1995. Cloning and expression of four novel isoforms of human interleukin-1 $\beta$ converting enzyme with different apoptotic activities. /. Biol. Chem. 270: 4312-4317.

Armstrong, J.F., M.H. Kaufman, D.J. Harrison, and A.R. Clarke. 1995. High-frequency developmental abnormalities in p53deficient mice. Curr. Biol. 5: 931-936.

Bakhshi, A., J.P. Jensen, P. Goldman, J.J. Wright, O.W. McBride, A.L. Epstein, and S.J. Korsmeyer. 1985. Cloning the chromosomal break-point of the $t(14: 18)$ human lymphomas: Cloustering around $\mathrm{JH}$ on Chromosome 14 and near a transcriptional unit on 18. Cell 41: 889-906.

Bardeesy, N., I.B. Beckwith, and J. Pelletier. 1995. Clonal expansion and attenuated apoptosis in Wilms' tumors are associated with p53 gene mutations. Cancer Res. 55: 215-219.

Birnbaum, M.J., R.J. Clem, and L.K. Miller. 1994. An apoptosisinhibiting gene from a nuclear polyhedrosis virus encoding a peptide with cys/his motifs. I. Virol. 68: 2521-2528.

Bissonnette, R.P., F. Echeverri, A. Mahboubi, and D. Green. 1992. Apoptotic cell death induced by $\mathrm{c}-\mathrm{myc}$ is inhibited by bcl-2. Nature 359: 552-554.

Boise, L.H., M. Gonzalez-Garcia, C.E. Postema, L. Ding, T. Lindsten, L.A. Turka, X. Mao, G. Nuñez, and C. Thompson. 1993. $b c l-x$, a $b c l$-2-related gene that functions as a dominant regulator of apoptotic death. Cell 74: 597-608.

Boldin, M.P., E.E. Varfolomeev, Z. Pancer, I.L. Mett, J.H. Camonis, and D. Wallach. 1995. A novel protein that interacts with the death domain of Fas/APO1 contains a sequence motif related to the death domain. J. Biol. Chem. 270: 77957798.

Boyd, J., S. Malstrom, T. Subramanian, L. Venkatesh, U. Schaeper, B. Elangovan, C. D'Sa-Eipper, and G. Chinnadurai. 1994. Adenovirus ElB $19 \mathrm{kDa}$ and bcl-2 proteins interact with a common set of cellular proteins. Cell 79: 341-351.

Boyd, J.M., G.J. Gallo, B. Elangovan, A.B. Houghton, S. Malstrom, B.J. Avery, R.G. Ebb, T. Subramanian, T. Chittenden, R.J. Lutz, and G. Chinnadurai. 1995. Bik1, a novel deathinducing protein shares a distinct sequence motif with Bcl-2 family proteins and interacts with viral and cellular survival-promoting proteins. Oncogene 11: 1921-1927.

Bump, N.J., M. Hackett, M. Hugunin, S. Seshagiri, K. Brady, P. Chen, C. Ferenz, S. Franklin, T. Ghayur, P. Li, P. Licari, J. Mankovich, L. Shi, A. Greenberg, L.K. Miller, and W.W. Wong. 1995. Inhibition of ICE family proteases by baculovirus anti-apoptotic protein p35. Science 269: 1885-1888.

Caelles, C., A. Helmberg, and M. Karin. 1994. p53-dependent apoptosis in the absence of transcriptional activation of p53target genes. Nature 370: 220-223.

Canman, C., T.M. Gilmer, S.B. Coutts, and M.B. Kastan. 1995. 
Growth factor modulation of p53-mediated growth arrest versus apoptosis. Genes \& Dev. 9: 600-611.

Chinnaiyan, A.M., K. O'Rourke, M. Tewari, and V.M. Dixit. 1995. FADD, a novel death domain-containing protein, interacts with the death domain of Fas and initiates apoptosis. Cell 81: 505-512.

Chiou, S.-K., L. Rao, and E. White. 1994a. Bcl-2 blocks p53dependent apoptosis. Mol. Cell. Biol. 14: 2556-2563.

Chiou, S.K., C.C. Tseng, L. Rao, and E. White. 1994b. Functional complementation of the adenovirus E1B $19 \mathrm{~K}$ protein with Bcl-2 in the inhibition of apoptosis in infected cells. $J$. Virol. 68: 6553-6566.

Chittenden, T., E.A. Harrington, R. O'Connor, C. Flemington, R.J. Lutz, G.I. Evan, and B.C. Guild. 1995a. Induction of apoptosis by the Bcl-2 homologue Bak. Nature 374: 733-736.

Chittenden, T., C. Flemmington, A.B. Houghton, R.G. Ebb, G.J. Gallo, B. Elangovan, G. Chinnadurai, and R.J. Lutz. 1995b. A conserved domain in Bak, distinct from $\mathrm{BH} 1$ and $\mathrm{BH} 2$, mediates cell death and protein binding functions. $E M B O F$. (in press).

Christofori, G., P. Naik, and D. Hanahan. 1994. A second signal supplied by insulin-like growth factor II in oncogene-induced tumorigenesis. Nature 369: 414-418.

Chu, K., X.H. Niu, and L.T. Williams. 1996. A novel protein, FAF-1, potentiates Fas-mediate apoptosis. Proc. Natl. Acad. Sci. (in press).

Clarke, A.R., E.R. Mandag, M. van Roon, N.M.T. van der Lugt, M. van der Valk, M.L. Hooper, A. Berns, and H. te Riele. 1992. Requirement for a functional Rb-l gene in murine development. Nature 359: 328-330.

Clarke, A.R., C.A. Purdie, D.J. Harrison, R.G. Morris, C.C. Bird, M.L. Hooper, and A.H. Wyllie. 1993. Thymocyte apoptosis induced by p53-dependent and independent pathways. $\mathrm{Na}$ ture 362: 849-852.

Clarke, A., S. Gledhill, M.L. Hooper, C.C. Bird, and A.H. Wyllie. 1994. p53 dependence of early apoptotic and proliferative responses within the mouse intestinal epithelium following $\gamma$-irradiation. Oncogene 9: 1767-1773.

Cleary, M.L., S.D. Smith, and J. Sklar. 1986. Cloning and structural analysis of cDNAs for bcl-2 and a hybrid bcl-2/immunoglobulin transcript resulting from the $t(14 ; 18)$ translocation. Cell 47: 19-28.

Clem, R.J. and L.K. Miller. 1993. Apoptosis reduces both the in vitro replication and in vivo infectivity of a baculovirus. I. Virol. 67: 3730-3738.

- 1994. Control of programmed cell death by the baculovirus genes p35 and iap. Mol. Cell. Biol. 14: 5212-5222.

Clem, R.J., M. Fechheimer, and L.K. Miller. 1991. Prevention of apoptosis by a Baculovirus gene during infection of insect cells. Science 254: 1388-1390.

Cleveland, J.L. and J.N. Ihle. 1995. Contenders in FasL/TNF death signaling. Cell 81: 479-482.

Crook, N.E., R.J. Clem, and L.K. Miller. 1993. An apoptosisinhibiting baculovirus gene with a zinc finger-like motif. $J$. Virol. 67: 2168-2174.

Debbas, M. and E. White. 1993. Wild-type p53 mediates apoptosis by E1A which is inhibited by E1B. Genes \& Dev. 7: 546-554.

Deng, C., P. Zhang, W.J. Harper, S.J. Elledge, and P. Leder. 1995. Mice lacking $221^{\mathrm{CIP} 1 / \mathrm{WAF} 1}$ undergo normal development, but are defective in G1 checkpoint control. Cell 82: 675684.

Donehower, L.A., M. Harvey, B.L. Slagle, M.J. McArthur, C.A. Montgomery, J.S. Butel, and A. Bradley. 1992. Mice deficient for p53 are developmentally normal but susceptible to spontaneous tumors. Nature 356: 215-221.
El-Deiry, W.S., S.E. Kern, J.A. Pietenpol, K.W. Kinzler, and B. Vogelstein. 1992. Definition of a consensus binding site for p53. Nature Genet. 1: 45-49.

El-Deiry, W.S., T. Tokino, V.E. Velculescu, D.B. Levy, R. Parsons, J.M. Trent, D. Lin, E. Mercer, K.W. Kinzler, and B. Vogelstein. 1993. WAF1, a potential mediator of p53 tumor suppression. Cell 75: 817-825.

Ellis, H. and H.R. Horvitz. 1986. Genetic control of programmed cell death in in the nematode C. elegans. Cell 44: 817-829.

Enarl, M., H. Hug, and S. Nagata. 1995. Involvement of an ICElike protease in Fas-mediated apoptosis. Nature 375: 78-81.

Fanidi, A., E.A. Harrington, and G. Evan. 1992. Cooperative interaction between c-myc and bcl-2 proto-oncogenes. $\mathrm{Na}$ ture 359: 554-556.

Farlie, P.G., R. Dringen, S.M. Rees, G. Kannourakis, and O. Bernard. 1995. Bcl-2 transgene expression can protect neurons against developmental and induced cell death. Proc. Natl. Acad. Sci. 92: 4397-4401.

Farrow, S.N., J.H.M. White, I. Martinou, T. Raven, K.-T. Pun, C.J. Grinham, J.-C. Martinou, and R. Brown. 1995. Cloning of a bcl-2 homologue by interaction with adenovirus E1B 19K. Nature 374: 731-733.

Faucheu, C., A. Diu, A.W.E. Chan, A.-M. Blanchet, C. Miossec, F. Herve, V. Collard-Dutilleul, Y. Gu, R.A. Aldape, J.A. Lippke, C. Rocher, M.S.-S. Su, D.J. Livingston, T. Hercend, and J.-L. Lalanne. 1995. A novel human protease similar to the interleukin- $1 \beta$ converting enzyme induces apoptosis in transfected cells. EMBO /. 14: 1914-1922.

Fernandes-Alnemri, T., G. Litwack, and E. Alnemri. 1994. CPP32, a novel human apoptotic protein with homology to Caenorhabditis elegans cell death protein Ced-3 and mammalian Interleukin-1ß-converting enzyme. I. Biol. Chem. 269: 30761-30764.

-1995. Mch2, a new member of the apoptotic Ced-3/ICE cysteine protease gene family. Cancer Res. 55: 2737-2742.

Fernandez-Sarabia, M.J. and J.R. Bischoff. 1994. Bcl-2 associates with the ras-related protein R-ras p23. Nature 366: 274-275.

Gagliardini, V., P.A. Fernandez, R.K.K. Lee, H.C.A. Drexler, R.J. Rotello, M.C. Fishman, and J. Yuan. 1994. Prevention of vertebrate neuronal death by the crmA gene. Science 263: 826828.

Garcia, I., I. Martinou, Y. Tsujimoto, and J.-C. Martinou. 1992. Prevention of programmed cell death of sympathetic neurons by the bcl-2 proto-oncogene. Science 258: 302-304.

Golstein, P., D. Marguet, and V. Depraetere. 1995. Homology between Reaper and the cell death domains of Fas and TNFR1. Cell 81: 185-186.

Gooding, L.R., L. Aquino, P.J. Duerksen-Hughes, D. Day, T.M. Horton, S. Yei, and W.S.M. Wold. 1991. The E1B-19K protein of group $\mathrm{C}$ adenoviruses prevents cytolysis by tumor necrosis factor of human cells but not mouse cells. J. Virol. 65: 3083-3094.

Grether, M.E., J.M. Abrams, J. Agapite, K. White, and H. Steller. 1995. The head involution defective gene of Drospophila melanogaster functions in programmed cell death. Genes \& Dev. 9: 1694-1708.

Haas-Kogan, D.A., S.C. Kogan, D. Levi, P. Dazin, A. T'Ang, Y.-K. Fung, and M.A. Israel. 1995. Inhibition of apoptosis by the retinoblastoma gene product. EMBO I. 14: 461-472.

Haldar, S., N. Jena, and C. Croce. 1995. Inactivation of Bcl-2 by phosphorylation. Proc. Natl. Acad. Sci. 92: 4507-4511.

Han, J., P. Sabbatini, D. Perez, L. Rao, D. Modha, and E. White. 1996. The E1B 19K protein blocks apoptosis by interacting with and inhibiting the p53-inducible and death-promoting Bax protein. Genes \& Dev, 10: (in press).

Harper, J.W., G.R. Adami, N. Wei, K. Keyomarsi, and S.J. 
Elledge. 1993. The p21 cdk-interacting protein cip1 is a potent inhibitor of G1 cyclin-dependent kinases. Cell 75: 805816.

Harrington, E.A., M.R. Bennett, and G. Evan. 1994. c-Myc-induced apoptosis in fibroblasts is inhibited by specific cytokines. $E M B O$ \%. 13: 3286-3295.

Hashimoto, S., A. Ishii, and S. Yonehara. 1991. The ElB oncogene of adenovirus confers cellular resistance to cytotoxicity of tumor necrosis factor and monoclonal anti-Fas antibody. Int. Immunol. 3: 343-351.

Haupt, Y., S. Rowan, and M. Oren. 1995a. p53-mediated apoptosis in HeLa cells can be overcome by excess pRB. Oncogene 10: 1563-1571.

Haupt, Y., S. Rowan, E. Shaulian, K. Vousden, and M. Oren. 1995b. Induction of apoptosis in HeLa cells by transactivation-deficient p53. Genes \& Dev. 9: 2170-2183.

Hay, B.A., T. Wolff, and G.M. Rubin. 1994. Expression of baculovirus p35 prevents cell death on Drosophila. Development 120: 2121-2129.

Henderson, S., D. Huen, M. Rowe, C. Dawson, G. Johnson, and A. Rickinson. 1993. Epstein-Barr virus-coded BHRF1 protein, a viral homologue of Bcl-2, protects human B cells from programmed cell death. Proc. Natl. Acad. Sci. 90: 84798483.

Hengartner, M.O. and H.R. Horvitz. 1994a. C. elegans cell survival gene ced- 9 encodes a functional homolog of the mammalian proto-oncogene bcl-2. Cell 76: 665-676.

- 1994b. The ins and outs of programmed cell death during C. elegans development. Phil. Trans. R. Soc. 345: 243246.

- 1994c. Activation of C. elegans cell death protein Ced-9 by an amino-acid substitution in a domain conserved in Bcl2. Nature 369: 318-320.

Hengartner, M.O., R.E. Ellis, and H.R. Hovitz. 1992. Caenorhabditis elegans gene ced-9 protects cells from programmed cell death. Nature 356: $494-499$.

Hermeking, H. and D. Eick. 1994. Mediation of c-Myc-induced apoptosis by p53. Science 265: 2091-2093.

Hockenbery, D., G. Nuñez, C. Milliman, R.D. Schreiber, and S. Korsmeyer. 1990. Bcl-2 is an inner mitochondrial membrane protein that blocks programmed cell death. Nature 348: 334-336.

Hockenbery, D.M., M. Zutter, W. Hickey, M. Nahm, and S.J. Korsmeyer. 1991. Bcl-2 protein is topographically restricted in tissues characterized by apoptotic death. Proc. Natl. Acad. Sci. 88: 6961-6965.

Hockenbery, D.M., Z.N. Oltvai, X.-M. Yin, C.L. Milliman, and S.J. Korsmeyer. 1993. Bcl-2 functions in an antioxidant pathway to prevent apoptosis. Cell 75: 241-251.

Hollstein, M., D. Sidransky, B. Vogelstein, and C. Harris. 1991. p53 mutations in human cancers. Science 253: 49-53.

Howes, K.A., N. Ransom, D.S. Papermaster, J.G.H. Lasudry, D.M. Albert, and J.J. Windle. 1994. Apoptosis or retinoblastoma: Alternative fates of photoreceptors expressing the HPV-16 E7 gene in the presence or absence of p53. Genes \& Dev. 8: $1300-1310$.

Hsu, H., J. Xiong, and D.V. Goeddel. 1995. The TNF receptor 1-associated protein TRADD signals cell death and NFkB activation. Cell 81: 495-504.

Jacks, T., A. Frzeli, E.M. Schmitt, R.T. Bronson, M.A. Goodell, and R.A. Weinberg. 1992. Effects of an Rb mutation in the mouse. Nature 359: 295-300.

Jacobson, M. and M.C. Raff. 1995. Programmed cell death and Bcl-2 protection in very low oxygen. Nature 374: 814-816.

Jacobson, M.D., J.F. Burne, M.P. King, T. Miyashita, J.C. Reed, and M.C. Raff. 1993. Bcl-2 blocks apoptosis in cells lacking mitochondrial DNA. Nature 361: 365-369.

Jacobson, M.D., J.F. Burne, and M.C. Raff. 1994. Programmed cell death and Bcl-2 protection in the absence of a nucleus. EMBO J. 13: 1899-1910.

Jayaraman, L. and C. Prives. 1995. Activation of p53 sequencespecific DNA binding by short single strands of DNA requires the p53 C-terminus. Cell 81: 1021-1029.

Johnson, D.J., J.K. Schwarz, W.D. Cress, and J.R. Nevins. 1993. Expression of transcription factor E2F1 induces quiescent cells to enter S phase. Nature 365: 349-352.

Kamada, S., A.A. Shinto, Y. Tsujimura, T. Takahashi, T. Noda, Y. Kitamura, H. Kondoh, and Y. Tsujimoto. 1995. Bcl-2 deficiency in mice leads to pleiotropic abnormalities: Accelerated lymphoid cell death in the thymus and spleen, polycystic kidney, hair hypopigmentation, and distorted small intestine. Cancer Res. 55: 354-359.

Kamens, J., M. Paskind, M. Huguinin, R.V. Talanian, H. Allen, D. Banach, N. Bump, M. Hackett, C.G. Johnston, P. Li, J.A. Mankovitch, M. Terranova, and T. Ghayur. 1995. Identification and characteriation of Ich-2, a novel member of the interleukin-1 $\beta$-converting enzyme family of cysteine proteases. J. Biol. Chem. 270: 15250-15256.

Kane, D.J., T.A. Sarafian, R. Anton, H. Hahn, E. Butler Gralla, J. Selverstone Valentine, T. Ord, and D.E. Bredesen. 1993. $\mathrm{Bcl}-2$ inhibition of neuronal death: Decreased generation of reactive oxygen radical species. Science 262: 1274-1277.

Kiefer, M.C., M.J. Brauer, V.C. Powers, J.J. Wu, S.R. Umansky, L.D. Tomei, and P.J. Barr. 1995. Modulation of apoptosis by the widely distributed Bcl-2 homolgue Bak. Nature 374: 736-739.

Knudson, C. M., K. Tung, G. Brown, and S.J. Korsmeyer. 1995. Bax deficient mice demonstrate lympoid hyperplasia but male germ cell death. Science 270: 96-99.

Komiyama, T., C.A. Ray, D.J. Pickup, A.D. Howard, N.A. Thornberry, E.P. Peterson, and G. Salvesen. 1994. Inhibition of interleukin- $1 \beta$ converting enzyme by the cowpox virus serpin CrmA. J. Biol. Chem. 269: 19331-19337.

Kowalik, T., J. DeGregori, J.K. Schwarz, and J. Nevins. 1995. E2F1 overexpression in quiescent fibroblasts leads to induction of cellular DNA synthesis and apoptosis. I. Virol. 69: 249l-2500.

Kozopas, K.M., T. Yang, H.L. Buchan, P. Zhou, and R.W. Craig. 1993. MCL1, a gene expressed in programmed myeloid cell differentiation, has sequence similarity to BCL-2. Proc. Natl. Acad. Sci. 90: 3516-3520.

Krajewski, S., M. Krajewska, A. Shabaik, T. Miyashita, H.G. Wang, and J.C. Reed. 1994. Immunohistochemical determination of in vivo distribution of $\mathrm{Bax}$, a dominant inhibitor of Bcl-2. Am. I. Pathol. 145: 1323-1336.

Kuida, K., J.A. Lippke, G. Ku, M.W. Harding, D.J. Livingston, M.S.-S. Su, and R.A. Flavell. 1995. Altered cytokine export and apoptosis in mice deficient in interleukin-1 $\beta$ converting enzyme. Science 267: 2000-2003.

Kumar, S., M. Kinoshita, M. Noda, N.G. Copeland, and N.A. Jenkins. 1994. Induction of apoptosis by the mouse Nedd2 gene, which encodes a protein similar to the product of the Caenorhabditis elegans cell death gene ced-3 and the mammalian IL-1 $\beta$-converting enzyme. Genes \& Dev. 8: 16131626.

Lazebnik, Y., S. Cole, C.A. Cooke, W.G. Nelson, and W.C. Earnshaw. 1993. Nuclear events of apoptosis in vitro in cell-free mitotic extracts: A model system for analysis of the active phase of apoptosis. I. Cell Biol. 123: 7-22.

Lazebnik, Y.A., S.H. Kaufmann, S. Desnoyers, G.G. Poirier, and W.C. Earnshaw. 1994. Cleavage of poly(ADP-ribose) polymerase by a proteinase with properties like ICE. Nature 
371: $346-347$

Lazebnik, Y.A. Takahashi, R. Moir, R. Goldman, G. Poirier, S. Kaufmann, and W. Earnshaw. 1995. Studies of the lamin proteinase reveal multiple parallel biochemical pathways during apoptotic execution. Proc. Natl. Acad. Sci. (in press).

LeBrun, D.P., R.A. Warnke, and M.L. Cleary. 1993. Expression of $b c l-2$ in fetal tissues suggests role in morphogenesis. Am. I. Pathol. 142: 743-753.

Lee, E.Y.-H.P., C.-Y. Chang, N. Hu, Y.-C.J. Wang, C.-C. Lai, K. Herrup, W.-H. Lee, and A. Bradley. 1992. Mice deficient for $\mathrm{Rb}$ are nonviable and show defects in neurogenesis and haematopoiesis. Nature 359: 288-294.

Lee, S., B. Elenbass, A.J. Levine, and J. Griffith. 1995. p53 and its $14 \mathrm{kDa} \mathrm{C}$-terminal domain recognize primary DNA demage in the form of insertion/deletion mismatches. Cell 81: 1013-1020.

Lefebvre, S., L. Burglen, S. Reboullet, O. Clermont, P. Burlet, L. Viollet, B. Benichou, C. Cruaud, Z. Millasseau, M. Zeviani, D. Le Paslier, J. Frezal, D. Cohen, J. Weissenbach, A. Munnch, and J. Melki. 1995. Identification and characterization of a spinal muscular atrophy-determining gene. Cell 80: $155-165$.

Li, P., A. Hamish, S. Banejee, S. Franklin, L. Herzog, C. Johnston, J. McDowell, M. Paskind, L. Rodman, J. Salfeld, E. Towne, D. Tracey, S. Wardwell, F.-Y. Wei, W. Wong, R. Kamen, and T. Seshardi. 1995. Mice deficient in IL-1 $\beta$-converting enzyme are defective in production of mature IL-1 $\beta$ and resistant to endotoxic shock. Cell 80: 401-411.

Lin, E.Y., A. Orlofsky, M.S. Berger, and M.B. Prystowsky. 1993. Characterization of Al, a novel hemopoietic-specific early response gene with sequence similarity to $b c 1-2$. I. Immunol. 151: 1979-1988.

Lin, H.-J.L., V. Eivner, G.C. Prendergast, and E. White. 1995. Activated $\mathrm{H}$-ras rescues E1A-induced apoptosis and cooperates with E1A to overcome p53-dependent growth arrest. Mol. Cell. Biol. 15: 4536-4544.

Lin, J., J. Chen, B. Elenbaas, and A.J. Levine. 1994. Several hydrophobic amino acids in the p53 amino-terminal domain are required for transcriptional activation, binding to $\mathrm{mdm}-2$ and the adenovirus 5 E1B $55-\mathrm{kD}$ protein. Genes \& Dev. 8: $1235-1246$

Los, M., M. Van de Craen, L.C. Penning, H. Schenk, M. Westendorp, P. Baeuerle, W. Droge, P.H. Krammer, W. Fiers, and K. Schulze-Osthoff. 1995. Requirement of an ICE/CED-3 protease for Fas/APO-1-mediated apoptosis. Nature 375: 81-83.

Lowe, S. and H.E. Ruley. 1993. Stabilization of the p53 tumor suppressor is induced by adenovirus $-5 \mathrm{ElA}$ and accompanies apoptosis. Genes \& Dev. 7: 535-545.

Lowe, S.W., H.E. Ruley, T. Jacks, and D.E. Housman. 1993a. p53-dependent apoptosis modulates the cytotoxicity of anticancer agents. Cell 74: 957-967.

Lowe, S.W., E.M. Schmitt, S.W. Smith, B.A. Osborne, and T. Jacks. 1993b. p53 is required for radiation-induced apoptosis in mouse thymocytes. Nature 362: 847-849.

Mack, D.H., J. Vartikar, J.M. Pipas, and L. Laimins. 1993. Specific repression of TATA-mediated but not initiator-mediated transcription by wild-type p53. Nature 363: 281-283.

McDonnell, T.J. and S.J. Korsmeyer. 1991. Progression from lymphoid hyperplasia to high-grade malignant lymphoma in mice transgenic for the $t(14: 18)$. Nature 349: 254-256.

McDonnell, T.J., N. Deane, F.M. Platt, G. Nunez, U. Jaeger, J.P. McKearn, and S.J. Korsmeyer. 1989. bcl-2-immunoglobulin transgenic mice demonstrate extended $B$ cell survival and follicular lymphoproliferation. Cell 57: 79-88.

McKeon, F. 1991. Nuclear lamin proteins: domains required for nuclear targeting, assembly, and cell-cycle-regulated dynamics. Curr. Opin. Cell Biol. 3: 82-86.

Merritt, A.J., C.S. Potten, C.J. Kemp, J.A. Hickman, A. Balmain, D.P. Lane, and P.A. Hall. 1994. The role of p53 in spontaneous and radiation-induced apoptosis in the gastrointestinal tract of normal and p53-deficient mice. Cancer Res. 54: 614 617.

Miura, M., H. Zhu, R. Rotello, E.A. Hartwieg, and J. Yuan. 1993. Induction of apoptosis in fibroblasts by IL-1 $\beta$-converting enzyme, a mammalian homolog of the $C$. elegans cell death gene ced-3. Cell 75: 653-660.

Miyashita, T. and J.C. Reed. 1995. Tumor suppressor p53 is a direct transcriptional activator of the human bax gene. Cell 80: 293-299.

Miyashita, T., S. Krajewski, M. Krajewska, H.G. Wang, H.K. Lin, D.A. Liebermann, B. Hoffman, and J.C. Reed. 1994. Tumor suppressor $\mathrm{p} 53$ is a regulator of $b c l-2$ and bax gene expression in vitro and in vivo. Oncogene 9: 1799-1805.

Momand, J., G.P. Zambetti, D.C. Olson, D. George, and A.J. Levine. 1992. The mdm-2 oncogene product forms a complex with the $\mathrm{p} 53$ protein and inhibits p53-mediated transactivation. Cell 69: 1237-1245.

Morgenbesser, S.D., B.O. Williams, T. Jacks, and R.A. DePinho. 1994. p53-dependent apoptosis produced by Rb-deficiency in the developing mouse lens. Nature 371: 72-74.

Motoyama, N., F. Wang, K.A. Roth, H. Sawa, K. Nakayama, K. Nakayama, I. Negishi, S. Senju, Q. Zhang, S. Fujii, and D. Loh. 1995. Massive cell death of immature hematopoeitic cells and neurons in Bcl-x-deficient mice. Science 267: 1506-1510.

Munday, N.A., J.P. Vaillancourt, A. Ali, F.J. Casano, D.K. Miller, S.M. Molineaux, T.-T. Yamin, V.L. Yu, and D.W. Nicholson. 1995. Molecular cloning and pro-apoptotic activity of ICErel-II and ICErel-III, members of the ICE/CED-3 family of cysteine proteases. J. Biol. Chem. 270: 1587015876.

Nagata, S. and P. Golstein. 1995. The Fas death factor. Science 267: 1499-1456.

Nakashima, T., T. Sekiguchi, A. Kuraoka, K. Fukushima, Y. Shibata, S. Komiyama, and T. Nishimoto. 1993. Molecular cloning of a human cDNA encoding a novel protein, DAD1, whose defect causes apoptotic cell death in hamster BHK21 cells. Mol. Cell. Biol. 13: 6367-6374.

Nakayama, K.-I., K. Nakayama, I. Negishi, K. Kuida, Y. Shinkai, M.C. Louie, L.E. Fields, P.J. Lucas, V. Stewart, F.W. Alt, and D.Y. Loh. 1993. Disappearance of the lymphoid system in bcl-2 homozygous mutant chimeric mice. Science 261: $1584-1588$.

Nakayama, K., K. Nakayama, I. Negishi, K. Kuida, H. Sawa, and D.Y. Loh. 1994. Targeted disruption of bcl-2 alpha beta in mice- occurrence of grey hair, polycystic kidney disease, and lymphocytopenia. Proc. Natl. Acad. Sci. 91: 3700-3704.

Neamati, N., A. Fernandez, S. Wright, J. Kiefer, and D.J. McConkey. 1994. Degradation of Lamin Bl precedes oligonucleosomal DNA fragmentation in apoptotic thymocytes and isolated thymocyte nuclei. I. Immunol. 154: 1693-1700.

Neilan, J.G., Z. Lu, C.L. Afonzo, G.F. Kutish, M.D. Sussman, and D.L. Rock. 1993. An African swine fever virus gene with similarity to the proto-oncogene $b c l-2$ and the Epstein-Barr virus gene BHRF1. J. Virol. 67: 4391-4394.

Nevins, J.R. 1992. E2F: A link between the Rb tumor suppressor protein and viral oncoproteins. Science 258: 424-428.

Newmeyer, D.D., D.M. Farschon, and J.C. Reed. 1994. Cell-free apoptosis in Xenopus egg extracts: Inhibition by Bcl-2 and requirement for an organelle fraction enriched in mitochondia. Cell 79: 353-364. 
Nicholson, D.W., A. Ali, N.A. Thomberry, J.P. Vaillancourt, C.K. Ding, M. Gallant, Y. Gareau, P.R. Griffin, M. Labelle, Y.A. Lazebnik, N.A. Munday, S.M. Raju, M.E. Smulson, T.T. Yamin, V.L. Yu, and D.K. Miller. 1995. Identification and inhibition of the ICE/CED-3 protease necessary for mammalian apoptosis. Nature 376: 37-43.

Novack, D.V. and S.J. Korsmeyer. 1994. Bcl-2 protein expression during murine development. Am. J. Pathol. 145: 61-73.

Nuñez, G., D. Hockenbery, T.J. McDonnell, C.M. Sorensen, and S.J. Korsmeyer. 1991. Bcl-2 maintains B cell memory. Nature 353: 71-73.

Oberhammer, F.A., K. Hochegger, G. Froschl, R. Tiefenbacher, and M. Pavelka. 1994. Chromatin condensation during apoptosis is accompanied by degradation of lamin $\mathrm{A}+\mathrm{B}$, without enhanced activation of cdc2 kinase. I. Cell Biol. 126: $827-837$.

Oliner, J.D., J. Pietenpol, S. Thiagalingam, J. Gyuris, K.W. Kinzler, and B. Vogelstein. 1993. Oncoprotein MDM2 conceals the activation domain of tumor suppressor p53. Nature 362: 857-860.

Oltvai, Z.N., C.L. Millman, and S.J. Korsmeyer. 1993. Bcl-2 heterodimerizes in vivo with a conserved homolog, Bax, that accelerates programmed cell death. Cell 74: 609-619.

Owen-Schaub, L., W. Zhang, J.C. Cusack, L.S. Angelo, S.M. Santee, T. Fujiwara, J.A. Roth, A.B. Deisseroth, W.-W. Zhang, E. Kruzel, and R. Radinsky. 1995. Wild-type human p53 and a temperature-sensitive mutant induce Fas/Apo-l expression. Mol. Cell. Biol. 15: 3032-3040.

Pan, H. and A.E. Griep. 1994. Altered cell cycle regulation in the lens of HPV-16 E6 or E7 transgenic mice: Implications for tumor suppressor gene function in development. Genes \& Dev. 8: 1285-1299.

- 1995. Temporally distince patterns of p53-dependent and p53-independent apoptosis during mouse lens development. Genes \& Dev. 9: 2157-2169.

Prives, C. 1994. How loops, $\beta$ sheets, and $\alpha$ helices help us to understand p53. Cell 78: 543-546.

Qin, X.-Q., D.M. Livingston, W.G. Kaelin, and P.D. Adams. 1994. Deregulated transcription factor E2F-1 expression leads to S-phase entry and p53-mediated apoptosis. Proc. Natl. Acad. Sci. 91: 10918-10922.

Rabizadeh, S., D.J. LaCount, P.D. Friesen, and D.E. Bredesen. 1993. Expression of the baculovirus $p 35$ gene inhibits mammalian neuronal cell death. J. Neurochem. 61: 2318-2321.

Raff, M.C. 1992. Social controls on cell survival and cell death. Nature 356: 398-400.

Rao, L., M. Debbas, P. Sabbatini, D. Hockenberry, S. Korsmeyer, and E. White. 1992. The adenovirus ElA proteins induce apoptosis which is inhibited by the E1B $19 \mathrm{~K}$ and Bcl-2 proteins. Proc. Natl. Acad. Sci. 89: 7742-7746.

Ray, C.A., R.A. Black, S.R. Kronheim, T.A. Greenstreet, P.R. Sleath, G.S. Salvesen, and D.J. Pickup. 1992. Viral inhibition of inflammation: Cowpox virus encodes an inhibitor of the interleukin-1 $\beta$ converting enzyme. Cell 69: 597-604.

Reynolds, J.E., T. Yang, L.P. Qian, J.D. Jenkinson, P. Zhou, A. Eastman, and R.W. Craig. 1994. MCL-1, a member of the bcl-2 family, delays apoptosis induced by c-myc overexpression in Chinese hamster ovary cells. Cancer Res. 54: 63486352.

Roy, N., M.S. Mahadevan, M. McLean, G. Shutler, Z. Yaraghi, R. Farahani, S. Baird, A. Besner-Johnston, C. Lefebvre, X. Kang, M. Salih, H. Aubry, K. Tamai, X. Guan, P. Ioannoou, T.O. Crawford, P. de Jong, L. Surh, J. Ikeda, R.G. Korneluk, and A. MacKenzie. 1995. The gene for neuronal apoptosis inhibtory protein is partially deleted in indivduals with spinal muscular atrophy. Cell 80: 167-178.
Sabbatini, P., S.-K. Chiou, L. Rao, and E. White. 1995a. Modulation of $\mathrm{p} 53$-mediated transcription and apoptosis by the adenovirus E1B 19K protein. Mol. Cell. Biol. 15: 1060-1070.

Sabbatini, P., J. Lin, A.J. Levine, and E. White. 1995b. Essential role for p53-mediated transcription in apoptosis but not growth suppression. Genes \& Dev. 9: 2184-2192.

Sato, T., M. Hanada, S. Bodrug, S. Irie, N. Iwama, L. Boise, C.B. Thompson, E. Golemis, L. Fong, H.-G. Wang, and J.C. Reed. 1994. Interactions among members of the Bcl-2 family analyzed with a yeast two-hybrid system. Proc. Natl. Acad. Sci. 91: 9238-9242.

Sato, T., S. Irie, S. Kitada, and J.C. Reed. 1995. FAP-1: A protein tyrosine phosphatase that associates with Fas. Science 268: 411-415.

Schulze-Ostoff, K., H. Walczak, W. Droge, and P.H. Krammer. 1994. Cell nucleus and DNA fragmentation are not required for apoptosis. J. Cell Biol. 127: 15-20.

Sentman, C.L., J.R. Shutter, D. Hockenbery, O. Kanagawa, and S.J. Korsmeyer. 1991. bcl-2 inhibits multiple forms of apoptosis but not negative selection in thymocytes. Cell 67: 879888 .

Shan, B. and W.H. Lee. 1994. Deregulated expression of E2F-1 induces S-phase entry and leads to apoptosis. Mol. Cell. Biol. 14: 8166-8173.

Shen, Y. and T. Shenk. 1994. Relief of p53 mediated transcriptional repression by the adenovirus E1B $19-\mathrm{kDa}$ protein or the cellular Bcl-2 protein. Proc. Natl. Acad. Sci. 91: 89408944.

Shimizu, S., Y. Eguchl, H. Kosaka, W. Kamiike, H. Masuda, and Y. Tsujimoto. 1995. Prevention of hypoxia-induced cell death by Bcl-2 and Bcl-xL. Nature 374: 811-813.

Siegel, R.M., M. Katsumata, T. Miyashita, D. Louie, M.I. Greene, and J.C. Reed. 1992. Inhibition of thymocyte apoptosis and negative antigenic selection in bcl-2 transgenic mice. Proc. Natl. Acad. Sci. 89: 7003-7007.

Smith, C.A., T. Farrah, and R.G. Goodwin. 1994. The TNF receptor superfamily of cellular and viral proteins: Activation, costimulation, and death. Cell 76: 959-962.

Stanger, B.Z., P. Leder, T.-H. Lee, E. Kim, and B. Seed. 1995. RIP: A novel protein containing a death domain that interacts with FAS/Apo-1 (CD95) in yeast and causes cell death. Cell 81: $513-523$.

Strasser, A., A.W. Harris, and S. Cory. 1991. bcl-2 transgene inhibits $\mathrm{T}$ cell death and perturbs thymic self-censorship. Cell 67: 889-899.

Strasser, A., A.W. Harris, L.M. Corcoran, and S. Cory. 1994. Bcl-2 expression promotes B- but not T-lymphoid development in scid mice. Nature 368: 457-460.

Sugimoto, A.P., P.D. Friesen, and J.H. Rothman. 1994. Baculovirus $p 35$ provents developmentally programmed cell death and rescues a ced-9 mutant in the nematode Caenorabditis elegans. EMBO J. 13: 2023-2028.

Sukamuro, D., V. Eviner, K.J. Elliot, L. Showe, E. White, and G.C. Prendergast. 1996. c-Myc induces apoptosis in epithelial cells by both p53-dependent and p53-independent mechanisms. Oncogene (in press).

Symonds, H., L. Krall, L. Remington, M. Saenz-Robies, S. Lowe, T. Jacks, and T. Van Dyke. 1994. p53-dependent apoptosis suppresses tumor growth and progression in vivo. Cell 78: 703-711.

Takayama, S., T. Sato, S. Krajewski, K. Kochel, S. Irie, J.A. Millan, and J.C. Reed. 1995. Cloning and functional analysis of Bag-1: A novel Bcl-2-binding protein with anti-cell death activity. Cell 80: 279-284.

Tewari, M. and V.M. Dixit. 1995. Fas- and TNF-induced apoptosis is inhibited by the poxvirus crmA gene product. J. Biol. 
Chem. 270: 3255-3260.

Tewari, M., L.T. Quan, K. O'Rourke, S. Desnoyers, Z. Zeng, D.R. Beidler, G. Poirier, G.S. Salvesen, and V.M. Dixit. 1995. Yama/CPP32 $\beta$, a mammalian homolog of CED-3, is a CrmA-inhibitable protease that cleaves the death substrate poly(ADP-ribose) polymerase. Cell 81: 801-809.

Thornberry, N.A., H.G. Bull, J.R. Calaycay, K.T. Chapman, A.D. Howard, M.J. Kostura, D.K. Miller, S.M. Molineaux, J.R. Weidner, and J. Aunins. 1992. A novel heterodimeric cysteine protease is required for interleukin- $1 \beta$ processing in monocytes. Nature 356: 768-774.

Tsujimoto, Y., J. Gorham, J. Cossman, E. Jaffe, and C.M. Croce. 1985. The $t(14 ; 18)$ chromosome translocations involved in $B$ cell neoplasms result from mistakes in VDJ joining. Science 229: 1390-1393.

Vaux, D.L., S. Cory, and T.M. Adams. 1988. Bcl-2 promotes the survival of haemopoietic cells and cooperates with $c-m y c$ to immortalize pre-B cells. Nature 335: 440-442.

Vaux, D.L., I.L. Weissman, and S.K. Kim. 1992. Prevention of programmed cell death in Caenorhabditis elegans by human bcl-2. Nature 258 1955-1957.

Veis, D.J., C.M. Sorenson, J.R. Shutter, and S.J. Korsmeyer. 1993. Bcl-2-deficient mice demonstrate fulminant lymphoid apoptosis, polycyctic kidneys, and hypopigmented hair. Cell 75: 229-240.

Vogelstein, B. 1990. A deadly inheritance. Nature 348: 681-682.

Wagner, A.J., J.M. Kokontis, and N. Hay. 1994. Myc-mediated apoptosis requires wild-type p53 in a manner independent of cell cycle arrest and the ability of p53 to induce p21waf1/ cip1. Genes \& Dev. 8: 2817-2830.

Walker, N., R. Talanian, K. Brady, L. Dang, N. Bump, C. Ferenz, S. Franklin, T. Ghayur, M.C. Hackett, L. Hammill, L. Herzog, M. Hugunin, W. Houy, J. Mankovich, L. McGuiness, E. Orlewicz, M. Paskind, C. Pratt, P. Reis, A. Summani, M. Terranova, J. Welch, L. Xiong, A. Moller, D. Tracey, R. Kamen, and W. Wong. 1994. Crystal structure of the cysteine protease interleukin-1 $\beta$-converting enzyme: A $(\mathrm{p} 20 / \mathrm{p} 10)_{2}$ homodimer. Cell 78: 343-352.

Wang, H.-G., J.A. Milan, A.D. Cox, C.J. Der, U.R. Rapp, T. Beck, H. Zha, and J.C. Reed. 1995. R-ras promotes apoptosis caused by growth factor deprivation via a Bcl-2 suppressble mechanism. I. Cell Biol. 129: 1103-1114.

Wang, L., M. Miura, L. Bergeron, H. Zhu, and J. Yuan. 1994. Ich-1 an ICE/ced-3-related gene, encodes both positive and negative regulators of programmed cell death. Cell 78: 739750.

Wang, Z.-Q., B. Auer, L. Stingl, H. Berghammer, D. Haidacher, M. Schweiger, and E.F. Wagner. 1995. Mice lacking ADPRT and poly/ADP-ribosyl)ation develop normally but are susceptible to skin disease. Genes \& Dev. 9: 509-520.

White, E. 1994a. Function of the adenovirus E1B oncogene in infected and transformed cells. In Seminars in virology (ed. E. Fanning), pp. 341-348. Academic Press, London, UK.

1994b. p53, guardian of Rb. Nature 371: 21-22.

1995. Regulation of p53-dependent apoptosis by ElA and E1B. In Current topics in microbiology and immunology: The molecular repertoire of adenovirus (ed. W. Doerfler) pp. 33-58. Springer Verlag, Berlin/Heidelberg, Germany.

White, E. and R. Cipriani. 1990. Role of adenovirus E1B proteins in transformation: Altered organization of intermediate filaments in transformed cells that express the 19-kilodalton protein. Mol. Cell. Biol. 10: 120-130.

White, E. and B. Stillman. 1987. Expression of the adenovirus E1B mutant phenotypes is dependent on the host cell and on synthesis of E1A proteins. J. Virol. 61: 426-435.

White, E., R. Cipriani, P. Sabbatini, and A. Denton. 1991. The adenovirus E1B 19-Kilodalton protein overcomes the cytotoxicity of ElA proteins. J. Virol. 65: 2968-2978.

White, E., P. Sabbatini, M. Debbas, W.S.M. Wold, D.I. Kusher, and L. Gooding. 1992. The 19-kilodalton adenovirus ElB transforming protein inhibits programmed cell death and prevents cytolysis by tumor necrosis factor $\alpha$. Mol. Cell. Biol. 12: 2570-2580.

White, K., M.E. Grether, J.M. Abrams, L. Young, K. Farrell, and H. Steller. 1994. Genetic control of programmed cell death in Drosophila. Science 264: 677-683.

Whyte, P., K. Buchkovich, J.M. Horowitz, S.H. Friend, M. Raybuck, R.A. Weinbert, and E. Harlow. 1988. Association be tween an oncogene and an anti-oncogene: The adenovirus El A proteins bind to the retinoblastoma gene product. $\mathrm{Na}$ ture 334: 124-129.

Williams, M.S. and P.A. Henkart. 1994. Apoptotic cell death induced by intracellular proteolysis. I. Immunol. 153: 42474255.

Wilson, K.P., J.F. Black, J.A. Thomson, E.E. Kim, J.P. Griffith, M.A. Navia, M.A. Murcko, S.P. Chambers, R.A. Aldape, S.A. Raybuck, and D.J. Livingston. 1994. Structure and mechanism of interleukin-1 $\beta$ converting enzyme. Nature 370: $270-275$.

$\mathrm{Wu}, \mathrm{X}$. and A.J. Levine. 1994. p53 and E2F-1 cooperate to mediate apoptosis. Proc. Natl. Acad. Sci. 91: 3602-3606.

Wyllie, A.H. 1980. Cell death: The significance of apoptosis. Int. Rev. Cytol. 68: 251-306.

Xiong, Y., G. Hannon, H. Zhang, D. Casso, R. Kobayashi, and D. Beach. 1993. p21 is a universal inhibitor of cyclin kinases. Nature 366: 701-704.

Xue, D. and H.R. Horvitz. 1995. Inhibition of the Caenorhabditis elegans cell-death protease CED-3 by a CED-3 cleavage site in baculovirus p35 protein. Nature 377: 248-251.

Yang, E., J. Zha, J. Jockel, L.H. Boise, C.B. Thompson, and S.J. Korsmeyer. 1995. Bad, a heterodimeric partner for Bcl-xL and Bcl-2, displaces Bax and promotes cell death. Cell 80: 285291.

Yang, T., K.M. Kozopas, and R.W. Craig. 1995. The intracellular distribution and pattern of expression of Mcl-2 overlap with but are not identical to, those of Bcl-2. I. Cell Biol. 128: $1173-1184$.

Yin, X.-M., Z. Oltvai, and S. Korsmeyer. 1994. BH1 and BH2 domains of Bcl-2 are required for inhibition of apoptosis and heterodimerization with Bax. Nature 369: 321-323.

Yonish-Rouach, E., D. Resnitzky, J. Lotem, L. Sachs, A. Kimchi, and M. Oren. 1991. Wild-type p53 induces apoptosis of myeloid leukaemic cells that is inhibited by interleukin-6. $\mathrm{Na}$ ture 352: 345-347.

Yonish-Rouach, E., V. Deguin, T. Zaitchouk, C. Breugnot, Z. Mishal, J. Jenkins, and E. May. 1996. Transcriptional activation plays a role in the induction of apoptosis by transientlytransfected wild-type p53. Oncogene (in press).

Yuan, J., S. Shaham, S. Ledoux, H.M. Ellis, and H.R. Horvitz. 1993. The C. elegans cell death gene ced- 3 encodes a protein similar to mammalian interleukin- $1 \beta$-converting enzyme. Cell 75: 641-652.

Zheng, H., D. Fletcher, W. Kozak, M. Jiang, K. Hofmann, C.A. Conn, D. Soszynski, C. Grablec, M. Trumbauer, A. Shaw, M.J. Kastura, K. Stevens, H. Rosen, R.J. North, H.Y. Chen, M.J. Tocci, M.J. Kluger, and L.H. Van der Ploeg. 1995. Resistance to fever induction and impaired acute phase response in interleukin-1 $\beta$ deficient mice. Immunity 3:9-19.

Ziegler, A., A.S. Jonason, D.J. Leffell, J.A. Simon, H.W. Sharma, J. Kimmelman, L. Remington, T. Jacks, and D.E. Brash. 1994. Sunburn and p53 in the onset of skin cancer. Nature 372: $773-776$ 


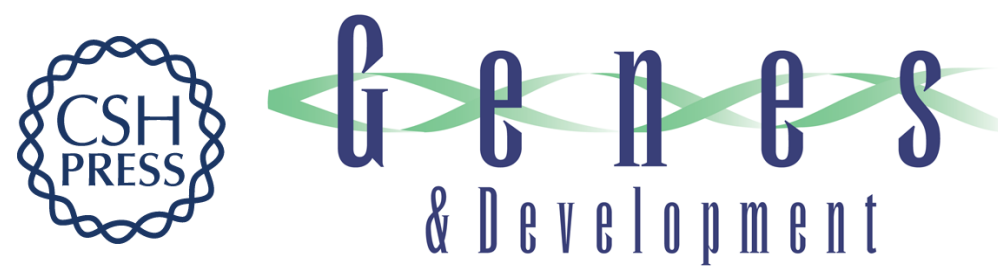

\section{Life, death, and the pursuit of apoptosis.}

E White

Genes Dev. 1996, 10:

Access the most recent version at doi:10.1101/gad.10.1.1

References This article cites 184 articles, 78 of which can be accessed free at:

http://genesdev.cshlp.org/content/10/1/1.full.html\#ref-list-1

License

Email Alerting Receive free email alerts when new articles cite this article - sign up in the box at the top Service right corner of the article or click here.

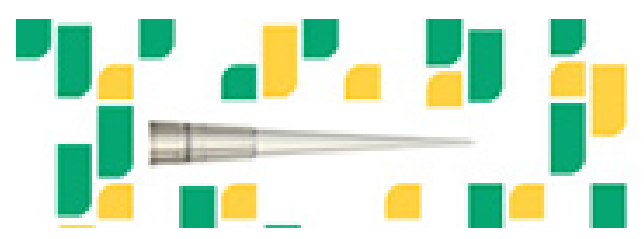

Focused on your science.

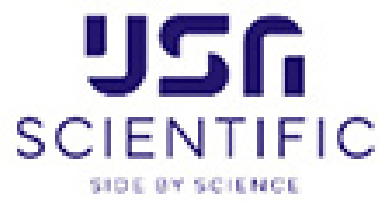

Copyright (c) Cold Spring Harbor Laboratory Press 